\title{
Article
}

\section{Geographic Variability and Anti-Staphylococcal Activity of the Chrysophaentins and Their Synthetic Fragments}

\author{
Jessica L. Keffer ${ }^{1}$, Jared T. Hammill ${ }^{2}$, John R. Lloyd ${ }^{1}$, Alberto Plaza ${ }^{1, \dagger}$, Peter Wipf ${ }^{2}$ and \\ Carole A. Bewley ${ }^{1, *}$
}

1 Laboratory of Bioorganic Chemistry, National Institute of Diabetes and Digestive and Kidney

Diseases, National Institutes of Health, Bethesda, MD 20892, USA;

E-Mails: kefferj@mail.nih.gov (J.L.K.); lloydj@niddk.nih.gov (J.R.L.);

a.plaza@mx.uni-saarland.de (A.P.)

2 Center for Chemical Methodologies and Library Development, University of Pittsburgh, Pittsburgh, PA 15260, USA; E-Mails: jth25@pitt.edu (J.T.H.); pwipf@pitt.edu (P.W.)

$\dagger$ Current address: Department of Pharmaceutical Biotechnology, Saarland University, 66123 Saarbrücken, Germany.

* Author to whom correspondence should be addressed; E-Mail: caroleb@ mail.nih.gov;

Tel.: +1-301-594-5187; Fax: +1-301-401-4192.

Received: 15 April 2012; in revised form: 5 May 2012 / Accepted: 7 May 2012 /

Published: 22 May 2012

\begin{abstract}
Drug-resistant Staphylococcus aureus is a continuing public health concern, both in the hospital and community settings. Antibacterial compounds that possess novel structural scaffolds and are effective against multiple $S$. aureus strains, including current drug-resistant ones, are needed. Previously, we have described the chrysophaentins, a family of bisdiarylbutene macrocycles from the chrysophyte alga Chrysophaeum taylori that inhibit the growth of $S$. aureus and methicillin-resistant $S$. aureus (MRSA). In this study we have analyzed the geographic variability of chrysophaentin production in C. taylori located at different sites on the island of St. John, U.S. Virgin Islands, and identified two new linear chrysophaentin analogs, E2 and E3. In addition, we have expanded the structure activity relationship through synthesis of fragments comprising conserved portions of the chrysophaentins, and determined the antimicrobial activity of natural chrysophaentins and their synthetic analogs against five diverse $S$. aureus strains. We find that the chrysophaentins show similar activity against all $S$. aureus strains, regardless of their drug sensitivity profiles. The synthetic chrysophaentin fragments indeed mimic the natural compounds in their spectrum of antibacterial activity, and therefore
\end{abstract}


represent logical starting points for future medicinal chemistry studies of the natural products and their analogs.

Keywords: chrysophaentins; Staphylococcus aureus; antibacterial

\section{Introduction}

Staphylococcus aureus has long been a public health concern, and is currently the leading cause of skin, soft tissue, bloodstream, and lower respiratory tract bacterial infections [1]. Penicillin was discovered in 1928 and first used in 1941, but by the late 1940's was ineffective due to the rise in penicillinase-producing $S$. aureus [2,3]. Methicillin was introduced into the clinic to combat penicillin-resistant strains, but not long after its introduction, the first case of methicillin-resistant S. aureus (MRSA) was described [4,5]. In the late 1980s and 1990s, the proportion of methicillin resistant infections rose significantly compared to susceptible ones worldwide [6]. In the United States, $S$. aureus is the leading cause of hospital-acquired infections [7]. Most of these strains are methicillin-resistant, and in the early 2000's, more patients in the U.S. succumbed to lethal MRSA infections than to AIDS, tuberculosis, and hepatitis B combined [8].

The public health threat involving MRSA is not just limited to the spread of antibacterial resistance; the movement of MRSA infections out of hospital settings and into the community is of great concern. These community-associated MRSA (CA-MRSA) strains have become so prevalent in the United States that almost everyone can be considered at risk for these infections [9,10]. CA-MRSA infections present unique challenges to their treatment because they are distinct from hospital-acquired MRSA (HA-MRSA) from an epidemiological, genetic, and clinical perspective [11,12]. CA-MRSA strains generally have a faster growth rate than hospital acquired strains, but are less resistant to antibacterials [13]. These bacteria typically contain a type IV staphylococcal cassette chromosome mec type IV gene (SCC mec IV) and are capable of producing the extracellular cytotoxin Panton-Valentine leukocidin (PVL) [14,15]. In contrast, nosocomial S. aureus typically carry a type I, II, or III staphylococcal cassette chromosome mec. CA-MRSA is fully virulent, perhaps even more so than HA-MRSA, and can produce other toxins that vary by geographic location $[16,17]$. In the United States, there are two distinct community-associated backgrounds that comprise the majority of CA-MRSA infections, namely USA300 and USA400. USA400 was first identified, but for reasons not completely understood, USA300 has become the predominant infectious CA-MRSA clone [7,18,19], currently accounting for 90-95\% of CA-MRSA outpatient isolates in the US [13,20,21]. One reason for its relative success and apparent fitness advantage may be its increased virulence. In a rat pneumonia model, researchers have shown increased pathogenicity that correlates with increased expression of virulence genes and increased expression of $S$. aureus regulatory systems [17,22].

The decline in antibacterial drug discovery programs worldwide has led to a concurrent decrease in the number of new antibacterial compounds [23]. This decline is apparent from the decrease in the number of antibacterial drugs (not including vaccines) approved for use from 1981-2010. During this period, 56 drugs were approved from 1981-1990, 32 were approved in 1991-2000, and only 16 were approved from 2001-2010 [24]. The increasing prevalence of resistance, even to drugs of last resort 
such as vancomycin, indicates that more new compounds are still needed [25,26]. These trends, combined with the knowledge that while incremental changes to lead compound scaffolds that result in increased potency and spectrum generally do not provide a permanent solution to combating resistance, suggest that new antibiotic compounds should differ structurally from earlier generation antibacterials.

Previously, we reported a suite of novel bisdiarlybutene macrocycles with antibacterial activity isolated from the marine chrysophyte alga, Chrysophaeum taylori, from St. John, U.S. Virgin Islands [27]. We found that these compounds have inhibitory activity against three drug-resistant Gram-positive organisms, and several drug-susceptible strains, and we developed a structure-activity relationship to explain their potencies. We made a subsequent collection from three locations on St. John, and have looked at geographic and temporal variability of chrysophaentin production. Furthermore, to address supply limitations of the natural products, we are working towards a total synthesis of the chrysophaentins, and have in hand two fragments from this effort. In this study, we have expanded the antibacterial activity and structure activity relationship of the natural chrysophaentins and two synthetic fragments to two additional $S$. aureus strains, $S$. aureus UAMS-1, a clinical osteomyelitis isolate, and CA-MRSA USA300-LAC. It was important to expand our library of S. aureus strains to include one with a more recent clinical, but still drug-susceptible, background, and a drug-resistant strain comprising the predominant and successfully invasive CA-MRSA USA300. We investigated the natural and synthetic chrysophaentin antibacterial activity to determine overall potency of growth inhibition and the mode of inhibition (bacteriostatic or bactericidal).

\section{Results and Discussion}

\subsection{Chrysophaeum taylori Collection and Chrysophaentin Identification}

The original chrysophaentins came from one collection of $C$. taylori made in Round Bay, located on the southern side of St. John, U.S. Virgin Islands, in July 2007. From this collection, we identified four asymmetrically linked macrocycles, chrysophaentins A-D (1-4); one linear analog, chrysophaentin E (5); and three symmetrically-linked macrocycles, chrysophaentins $\mathrm{F}-\mathrm{H}(\mathbf{8}-\mathbf{1 0})$ (Figure 1). The eight chrysophaentins were remarkably similar to one another. All possess an ether linkage between $\mathrm{C}-1$ and C-14'. If present, the second ether linkage was located between either C-14 or C-16 and C-1', and halogen variability only occurred at $\mathrm{C}-2$ and $\mathrm{C}-2^{\prime}$. Chrysophaentin $\mathrm{H}$ additionally differed in its pentahalogenation, with replacement of the hydrogen at $\mathrm{C}-12^{\prime}$ with a bromine.

To obtain additional raw material, we returned to St. John in June 2009 and made three collections at Round Bay, Long Bay, and Hawk's Nest (Figure 2). Each sample was dried and sequentially extracted with hexanes, chloroform, and methanol, and the chrysophaentins were found to be present in the methanol extract. Each methanolic extract from the three new collections plus the original collection were chromatographed by reverse-phase HPLC on a Jupiter Proteo C12 column with a linear gradient of $50-80 \%$ methanol in $0.05 \%$ TFA-water in fifty minutes. This afforded a chromatographic picture of the chrysophaentins present in each extract (Figure 3). The two collections from Round Bay (Figure 3A,C), separated by two years, were remarkably similar, as was the collection from Long Bay (Figure 3B). However, it was immediately obvious that the methanol extract from Hawk's Nest (Figure 3D) was different; in fact, it lacked the asymmetrically-linked chrysophaentins 
A-D. Instead, the linear chrysophaentin E was the most abundant, as well as two newly identified linear chrysophaentins, termed E2 and E3 (Figure 1, compounds 6 and 7). Algae collected from all locations contained the symmetrical chrysophaentins, albeit at much lower abundance relative to compounds A-E.

Figure 1. Structures of the natural chrysophaentins and synthetic fragments.
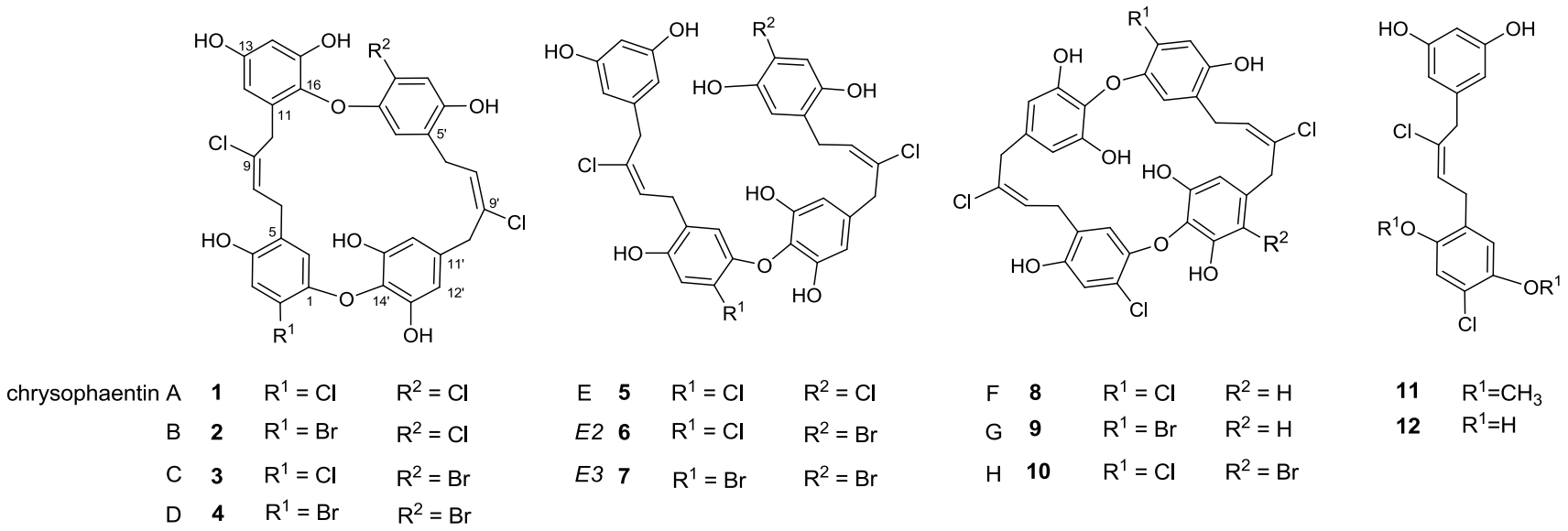
$\begin{array}{llll} & 5 & \mathrm{R}^{1}=\mathrm{Cl} & \mathrm{R}^{2}=\mathrm{Cl}\end{array}$
$\begin{array}{llll}\text { E2 } & 6 & \mathrm{R}^{1}=\mathrm{Cl} & \mathrm{R}^{2}=\mathrm{Br}\end{array}$
E3 $7 \quad \mathrm{R}^{1}=\mathrm{Br} \quad \mathrm{R}^{2}=\mathrm{Br}$

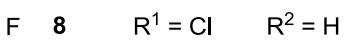
G $9 \quad \mathrm{R}^{1}=\mathrm{Br} \quad \mathrm{R}^{2}=\mathrm{H}$
$\mathrm{H} \quad 10 \quad \mathrm{R}^{1}=\mathrm{Cl} \quad \mathrm{R}^{2}=\mathrm{Br}$

$11 \mathrm{R}^{1}=\mathrm{CH}_{3}$

$12 \mathrm{R}^{1}=\mathrm{H}$

Figure 2. Locations of Chrysophaeum taylori collections on St. John, U.S. Virgin Islands. Collections were made Long Bay in 2009 (green pin), the northern tip of Round Bay in 2007 and 2009 (yellow pin), and on the north side of the island at Hawk's Nest in 2009 (red pin). Image was created using the Google Earth software package [28].

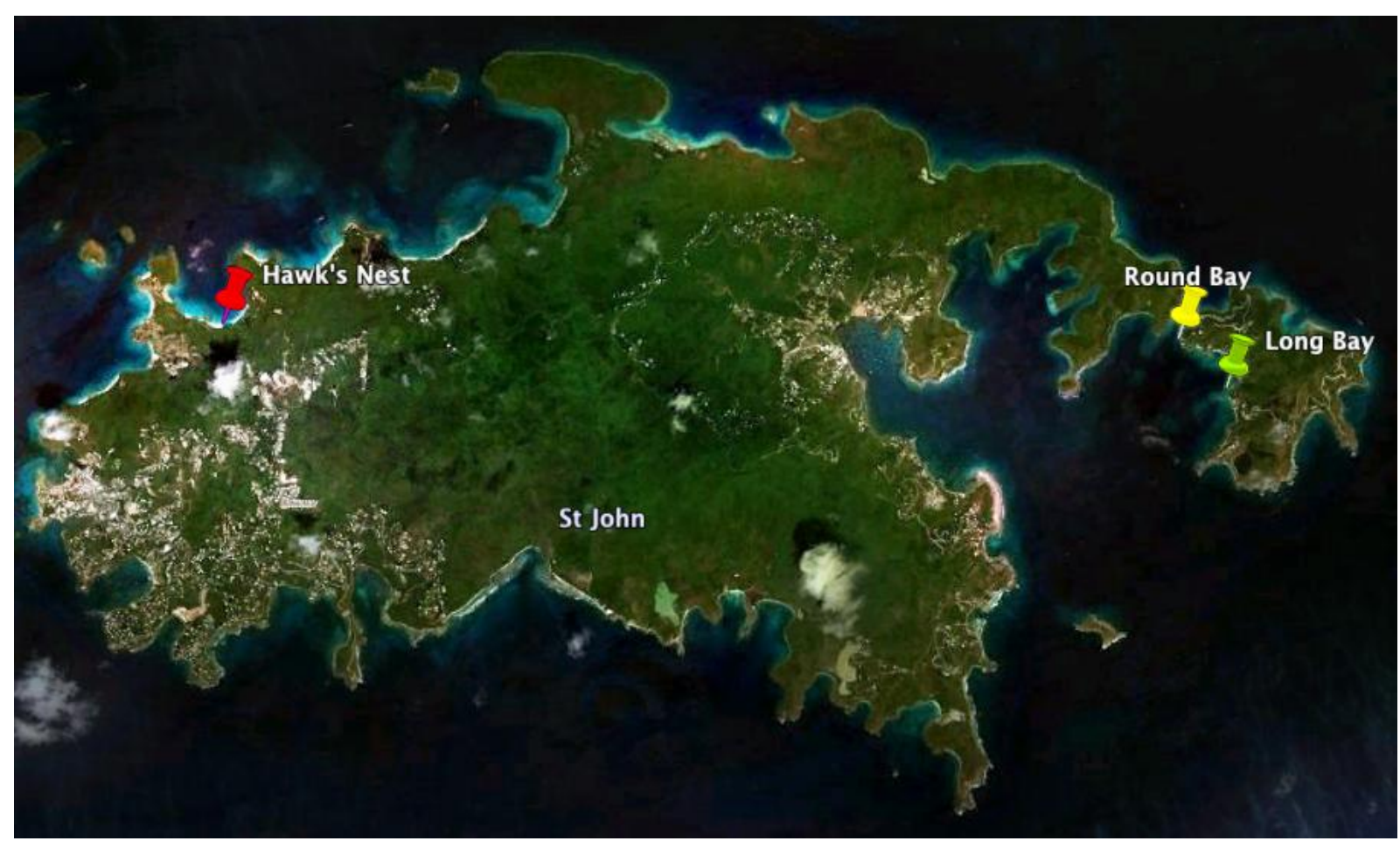


Figure 3. Geographic distribution of chrysophaentins determined by LCMS. Analytical HPLC chromatograms of $\mathrm{MeOH}$ extracts of four collections of Chrysophaeum taylori eluting with a linear gradient of $50-80 \% \mathrm{MeOH}$ in aq. $0.05 \% \mathrm{TFA}$ in $50 \mathrm{~min}$. Panels correspond to $C$. taylori extracts obtained from the following collections sites and dates: (A) Round Bay, 2007; (B) Long Bay, 2009; (C) Round Bay, 2009; (D) Hawk's Nest, 2009. The expansions shown correspond to the chromatograms at 28-42 min, and UV detection at $280 \mathrm{~nm}$. Peaks are colored as shown in the legend, panel A.

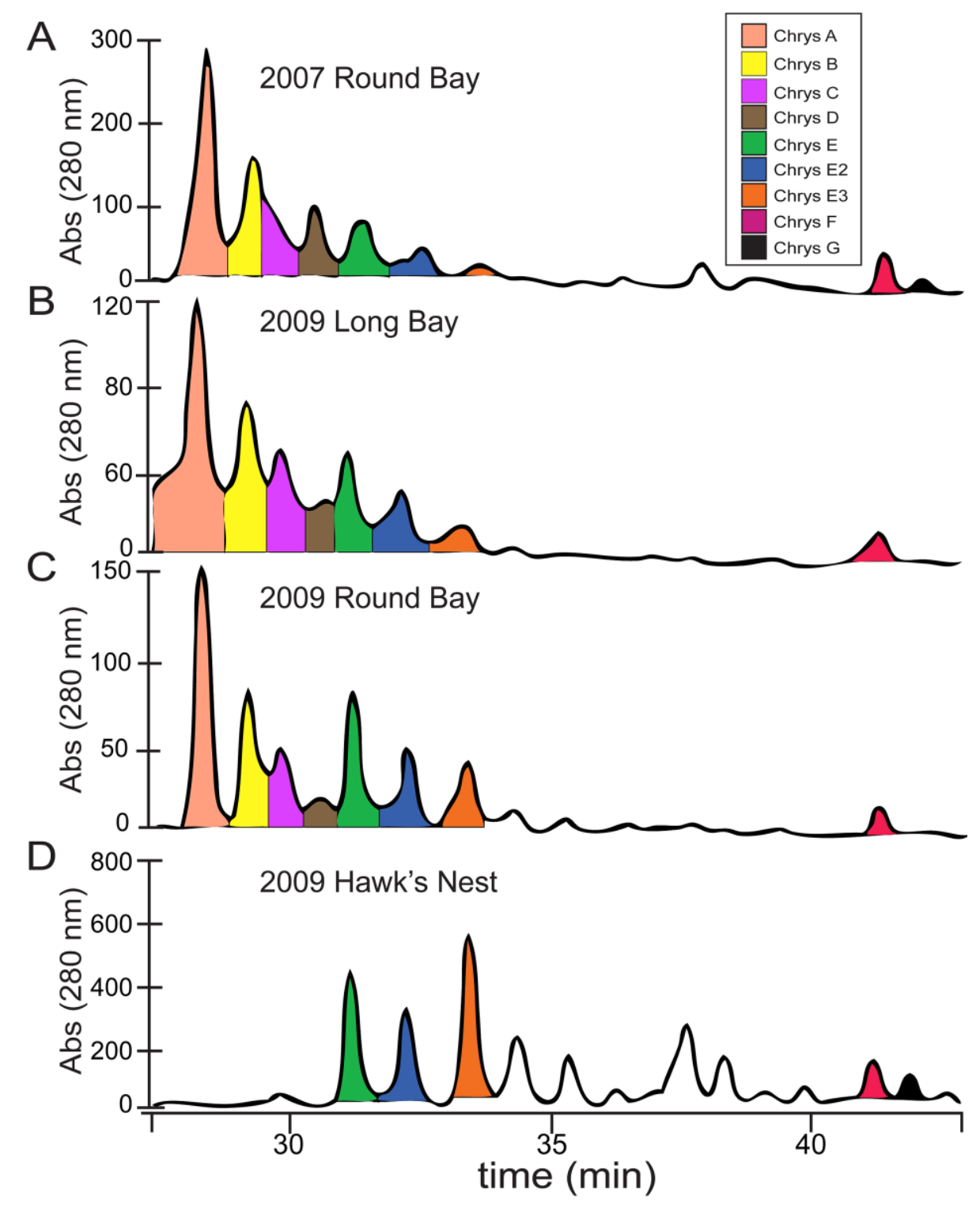

\subsection{Identification of New Acyclic Chrysophaentins}

Previously we determined the structure of acyclic chrysophaentin E (5), which has a molecular formula of $\mathrm{C}_{32} \mathrm{H}_{26} \mathrm{Cl}_{4} \mathrm{O}_{8}$ as determined by HR-MS and NMR. Chrysophaentins E2 (6) and E3 (7) were obtained in insufficient quantities for full NMR characterization. However, through analysis of the respective fragmentation patterns observed in the HR-ESI-MS data, we were able to assign structures for each of these new linear chrysophaentins. HR-ESI-MS showed chrysophaentin E2 to possess a molecular formula of $\mathrm{C}_{32} \mathrm{H}_{26} \mathrm{BrCl}_{3} \mathrm{O}_{8}\left(\mathrm{~m} / \mathrm{z} 720.9786[\mathrm{M}-\mathrm{H}]^{-}\right.$, calcd for $\left.\mathrm{C}_{32} \mathrm{H}_{25} \mathrm{BrCl}_{3} \mathrm{O}_{8}, 720.9798\right)$, 
and chrysophaentin $\mathrm{E} 3$ to possess a molecular formula of $\mathrm{C}_{32} \mathrm{H}_{26} \mathrm{Br}_{2} \mathrm{Cl}_{2} \mathrm{O}_{8}\left(\mathrm{~m} / \mathrm{z} 764.9282[\mathrm{M}-\mathrm{H}]^{-}\right.$, calcd for $\mathrm{C}_{32} \mathrm{H}_{25} \mathrm{Br}_{2} \mathrm{Cl}_{2} \mathrm{O}_{8}, 764.9293$ ), indicating that a bromine replaced a chlorine in $\mathrm{E} 2$ (6), and two bromines replaced two chlorines in E3 (7), when compared to chrysophaentin E (5). Since positions C-2 and C-2' were the only sites of halogen variability in the natural chrysophaentins, we reasoned that the dibrominated compound 7 likely contained a bromine at both of these carbons. On the other hand, chrysophaentin E2 must contain bromine at only one of these sites, with chlorine at the other. To identify the respective locations of chlorine and bromine in $\mathbf{6}$, we compared the mass fragmentation patterns of the three linear analogs (Figure 4). As seen in Figure 4A, the fragmentation pattern for chrysophaentin E showed the successive loss of four chlorine atoms, giving fragment ions with clear isotopic signatures at $m / z 641[\mathrm{M}-\mathrm{H}-\mathrm{HCl}]^{-}, 605[\mathrm{M}-\mathrm{H}-2 \mathrm{HCl}]^{-}, 569[\mathrm{M}-\mathrm{H}-3 \mathrm{HCl}]^{-}$, and $533[\mathrm{M}-\mathrm{H}-4 \mathrm{HCl}]^{-}$. The fragmentation pattern and peak intensities for chrysophaentin E2 (6) was very similar to 5 (Figure $4 \mathrm{~A}$ and $4 \mathrm{~B}$ ), where successive loss of three chlorines and one bromine gave rise to fragment ions at $m / z 685[\mathrm{M}-\mathrm{H}-\mathrm{HCl}]^{-}, 649[\mathrm{M}-\mathrm{H}-2 \mathrm{HCl}]^{-}, 613[\mathrm{M}-\mathrm{H}-3 \mathrm{HCl}]^{-}$, and $533[\mathrm{M}-\mathrm{H}-\mathrm{HBr}-3 \mathrm{HCl}]^{-}$. In contrast, although loss of two bromines and two chlorines was apparent in the mass spectrum for chrysophaentin E3, the major ion for 7 appeared at $m / z 395\left[\mathrm{M}-\mathrm{H}-\mathrm{HBr}-\mathrm{HCl}-\mathrm{C}_{16} \mathrm{H}_{14} \mathrm{O}_{3}\right]^{-}$, which corresponds to the fragment generated from cleavage at the ether bond (Figure 4C). Although MS data on model halogenated biaryl ethers was not available, our data suggest that the presence of bromine ortho to the ether bond is destabilizing as compared to chlorine in the same position, and facilitates cleavage at the ether bond in compound 7. Thus, the nearly identical mass spectral patterns observed for $\mathbf{5}$ and $\mathbf{6}$, and the unique fragmentation at the ether bond in the spectrum for 7, allow assignments of the structures of the new linear chrysophaentins E2 and E3, as shown in Figures 1 and 4.

Figure 4. HR-MS fragmentation of chrysophaentins E, E2, and E3. Fragmentation of (A) chrysophaentin E showing individual losses of four chlorine atoms; (B) chrysophaentin E2 showing loss of three chlorine atoms and one bromine atom; $(\mathbf{C})$ the major ion in the spectrum for chrysophaentin E3 corresponds to fragmentation at the ether bond, with weaker ions corresponding to loss of two chlorine and two bromine atoms.

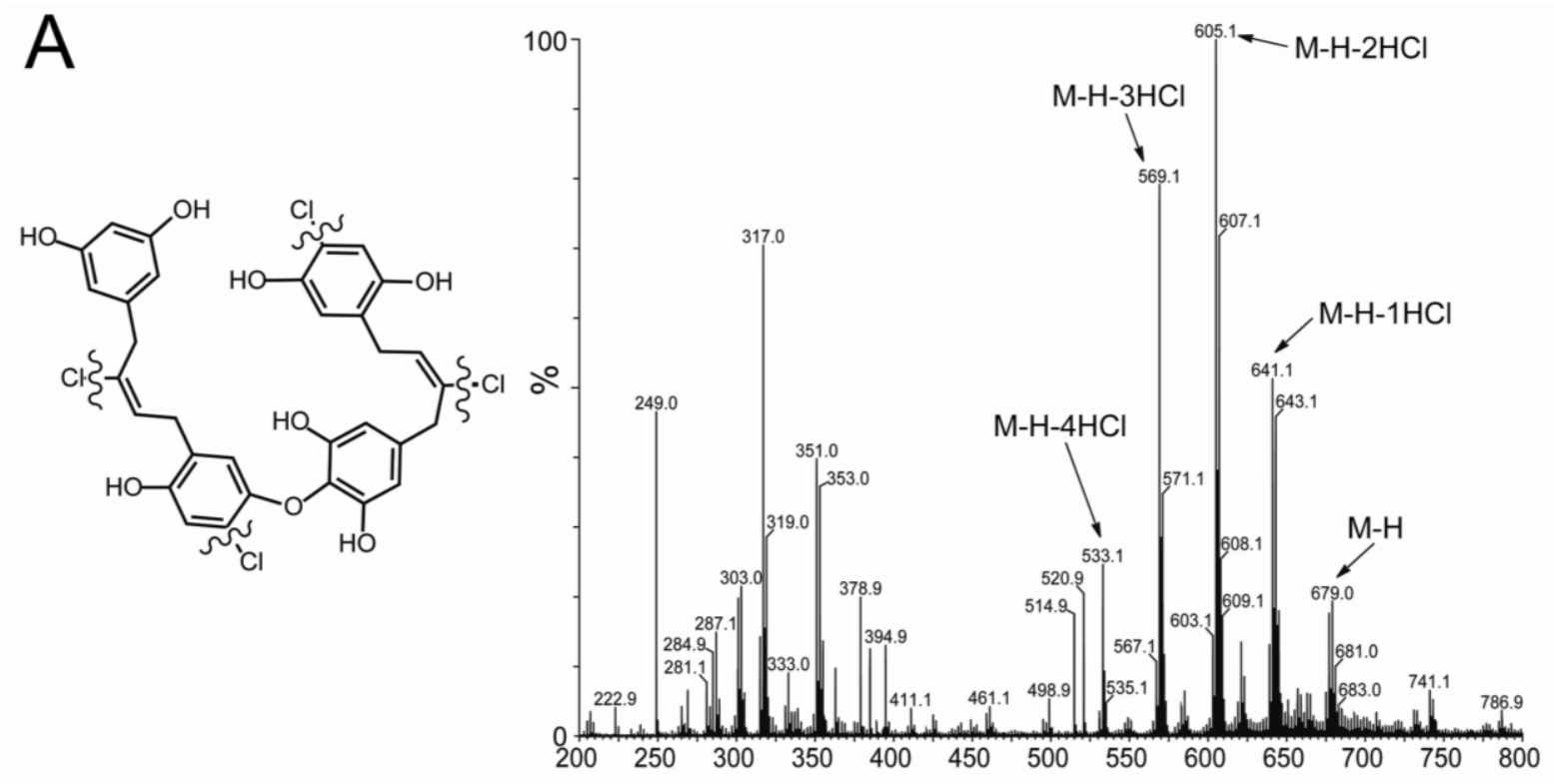


Figure 4. Cont.

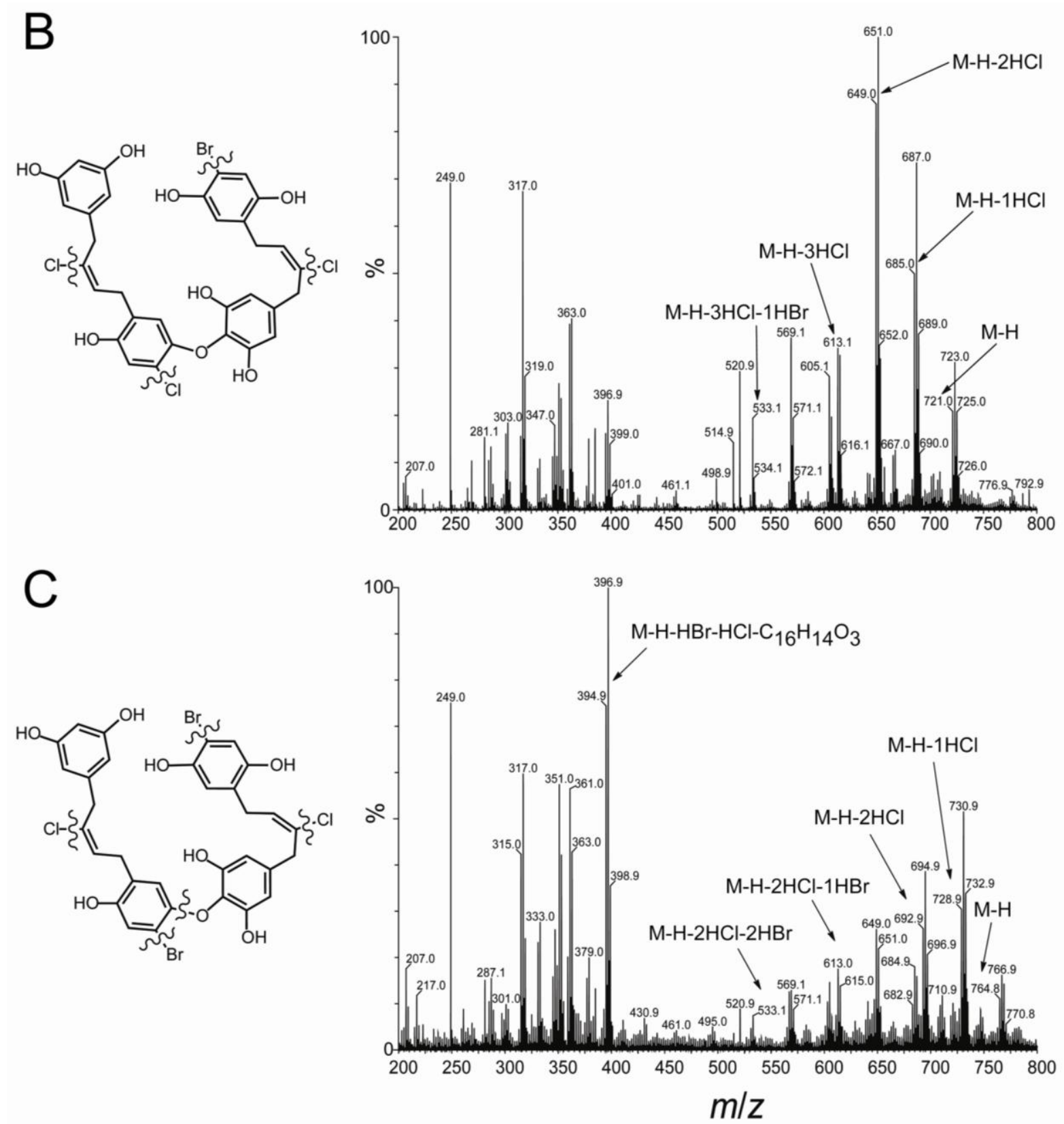

\subsection{Chrysophaentin Fragment Synthesis}

While the extracts from Long Bay and Round Bay afforded more of the asymmetrical chrysophaentins, it became apparent that a synthetic approach to chrysophaentin production was necessary in order to fully examine the biological activity of the structural variants. Accordingly, we devised a convergent synthetic strategy to allow for a total synthesis of the chrysophaentins as well as the investigation of structure-activity relationships. Fragment 12, which, in principle, could be used twice for the assembly of the diether $\mathbf{1}$, could be constructed by a key Negishi cross-coupling between vinyl iodide 13 and benzylic zinc species 14 (Scheme 1). A chloroiodination of alkyne 15 and a metalation of a halide derived from aldehyde 16 were envisioned to provide access to 13 and $\mathbf{1 4}$, respectively. In fact, while some modification of protective groups was required, this strategy could be readily realized. 
Scheme 1. Retrosynthetic approach toward chrysophaentin A (1).
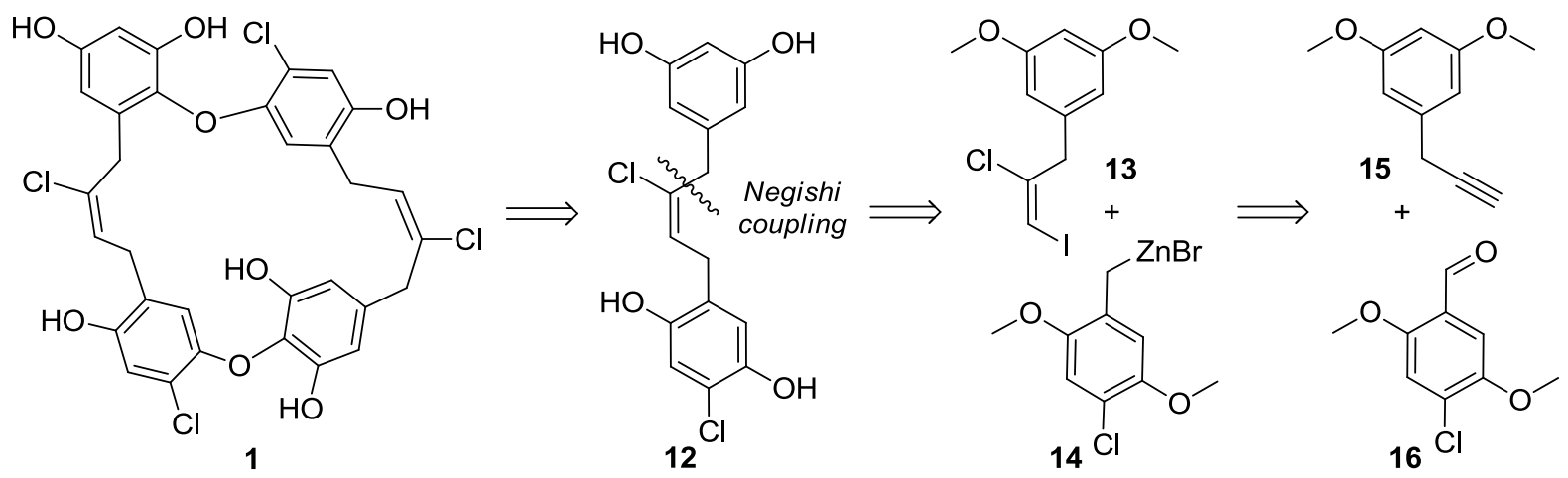

The commercially available benzoic acid 17 was reduced with lithium aluminumhydride (LAH) to the benzylalcohol 18 (Scheme 2). Bromination [29] and copper-catalyzed substitution with TMS-acetylene magnesium bromide [30] provided the alkyne $\mathbf{2 0}$ in $89 \%$ overall yield from $\mathbf{1 7}$. After desilylation of $\mathbf{2 0}$ with tetrabutylammonium fluoride (TBAF), dimethyl resorcinol $\mathbf{1 5}$ was subjected to iodochlorination $[31,32]$ in an attempt to generate 13. However, the desired alkyne addition product was formed to a minor extent, and mainly overiodination products were observed. Therefore, we demethylated 15 with boron tribromide and installed the deactivating pivaloyl esters in $82 \%$ yield. Iodochlorination of $\mathbf{2 1}$ now proceeded in excellent yield to give a 2:1 mixture of alkene isomers 22 and 23. While this ratio could be further improved in favor of the $(E)$-alkene 22 using solvents other than dichloromethane, yields were considerably lower. Furthermore, we were unable to separate the mixture at this stage, and the clean conversion in dichloromethane allowed us to carry it forward to the coupling step.

Scheme 2. Preparation of (E)-iodoalkene segment (22).

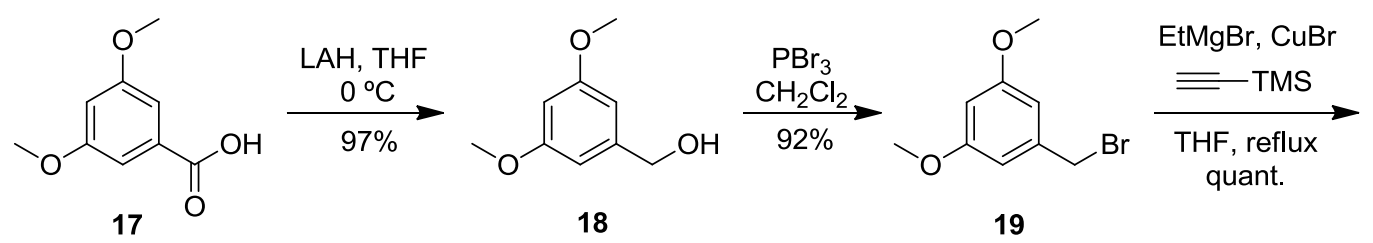

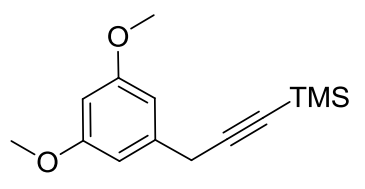

20

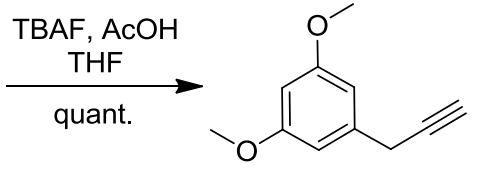

15

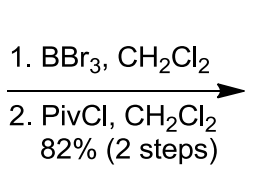

$\mathrm{PivCl}, \mathrm{CH}_{2} \mathrm{Cl}_{2}$
$82 \%(2$ steps $)$

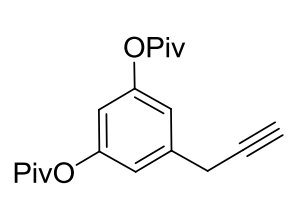

21

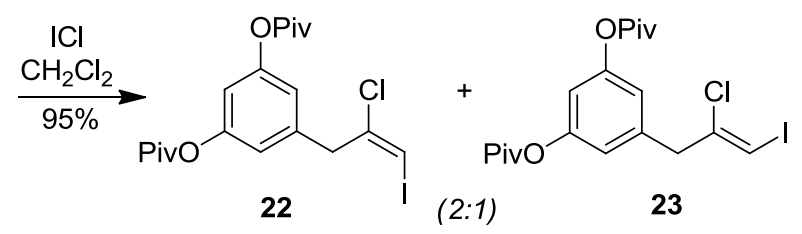

Formylation [33,34] of dimethyl hydroquinone $\mathbf{2 4}$ provided aldehyde $\mathbf{1 6}$, which was reduced to the alcohol 25 and brominated to give 26 in high yield (Scheme 3). Four equivalents of this bromide were then converted to the corresponding zinc reagent. Removal of excess zinc was necessary prior to 
combination with 22 and 23 and subsequent microwave heating in the presence of palladium acetate. These cross-coupling conditions [35] generated satisfactory yields of the chloroalkenes $\mathbf{1 1}$ and $\mathbf{2 7}$ in a 2:1 ratio after methanolysis of the pivaloate esters with cesium carbonate and methanol. An analytically pure sample of 11 was obtained by separation with supercritical fluid chromatography (SFC). Boron tribromide was used to cleave the two methyl ethers on 11 to give the tetraphenol 12, which was obtained as the pure $(E)$-isomer and further purified by preparative supercritical fluid chromatography (SFC) before submission to biological testing. In a control experiment, the use of a 2:1 mixture of 11 and $\mathbf{2 7}$ in the deprotection reaction led to a 2:1 mixture of $\mathbf{1 2}$ and its (Z)-diastereomer, as expected. The assignments of the E/Z-configurations of $\mathbf{1 2}$ and its (Z)-diasteromer as well as $\mathbf{2 2}$ and $\mathbf{2 3}$ were mainly based on the available literature data [31,32].

Scheme 3. Preparation of benzyl bromide segment (26) and Negishi coupling to give tetraphenol 12.
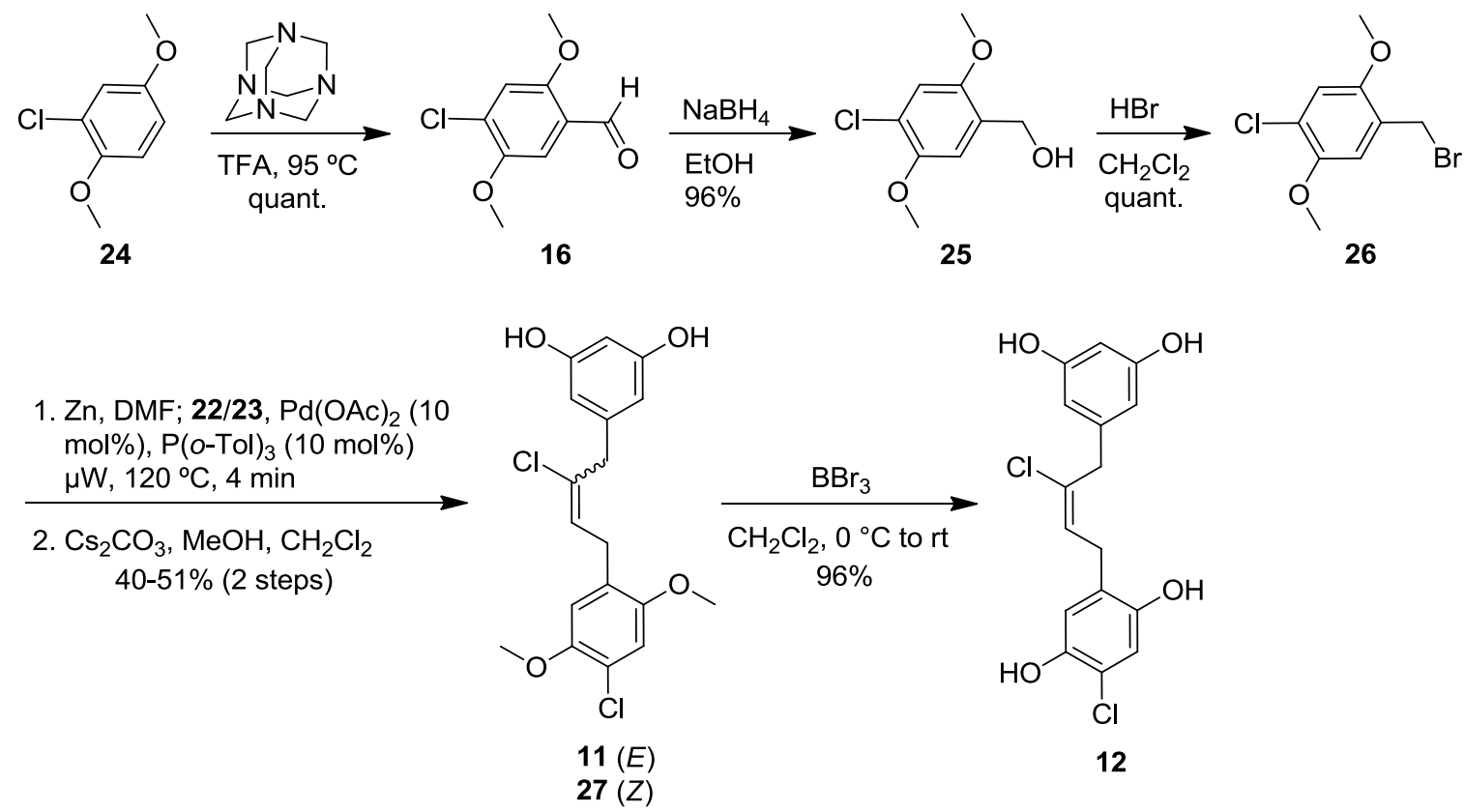

\subsection{Antibacterial Evaluation}

With the new fragments in hand, we tested whether their potencies were similar to the parent chrysophaentins. A microbroth dilution assay was used to evaluate the antibacterial activity of these compounds, and the minimum inhibitory concentration that led to a 50\% decrease in growth (MIC $\mathrm{M}_{50}$ ) was determined using a model curve fit to the data. The $\mathrm{MIC}_{90}$ was determined as the lowest concentration where there was no visible growth, and the minimum bactericidal concentration (MBC) was determined as the lowest concentration where a plated aliquot of treated bacteria led to a three logarithmic decrease in colony forming units (CFU) per milliliter relative to the starting inoculum. All compounds were evaluated against three different $S$. aureus strains from ATCC and two diverse clinical isolates. The strains used in this study included: S. aureus ATCC 25923, a clinical isolate from Seattle, 1945; methicillin-resistant $S$. aureus ATCC BAA-41, a hospital-acquired strain isolated in New York City in 1994; multidrug-resistant S. aureus (MDRSA) ATCC BAA-44, a hospital-acquired strain isolated in Lisbon, Portugal, with resistance towards ampicillin, methicillin, oxacillin, penicillin, 
erythromycin, gentamicin, tetracycline, azithromycin, amikacin, clindamycin, cephalothin, ceftriaxone, imipenem, lincomycin, streptomycin, perfloxacin, rifampin, and neomycin [6,36]; S. aureus UAMS-1, a clinical osteomyelitis isolate [37]; and community-associated methicillin-resistant S. aureus, USA300-LAC $[38,39]$.

\subsubsection{Minimum Bactericidal Concentrations for Select Natural Chrysophaentins}

The $\mathrm{MIC}_{50}$ for select chrysophaentins was reported previously [27]. Those qualitative antibacterial data have been expanded here to include descriptions of the $\mathrm{MIC}_{90}$ and the $\mathrm{MBC}$ for the chrysophaentins against $S$. aureus 25923, MRSA BAA-41, and MDRSA BAA-44. These values are summarized in Table 1. We found chrysophaentin A to inhibit the growth of $S$. aureus 25923, MRSA BAA-41 and MDRSA BAA-44 with $\mathrm{MIC}_{50}$ values on the order of 1-4 $\mu \mathrm{M}$, and $\mathrm{MIC}_{90}$ values ranging from 4-9 $\mu \mathrm{M}$ against all three strains. Chrysophaentin A was bacteriostatic at its $\mathrm{MIC}_{90}$, becoming bactericidal only at concentrations four to eight times higher than the $\mathrm{MIC}_{90}$. We have found chrysophaentin A to be the most potent compound in all of our antibacterial assays, yet chrysophaentins $\mathrm{F}$ and $\mathrm{H}$ which bear a symmetrical bisbibenzyl ether skeleton also inhibit S. aureus 25923 and MRSA BAA-41 with single digit micromolar $\mathrm{MIC}_{50} \mathrm{~s}$. While their $\mathrm{MIC}_{90}$ s were higher than those of chrysophaentin A (17-19 $\mu \mathrm{M})$, the MBC for chrysophaentin $\mathrm{F}$ was still four-fold higher than the $\mathrm{MIC}_{90}$. A significant reduction in potency was observed for the acyclic natural product chrysophaentin E (5), which was also bacteriostatic at its $\mathrm{MIC}_{90}$. Chrysophaentins D (4) and G (9), both of which contain a bromine atom on the $\mathrm{D}$ ring, were the least active compounds, with an 8- to13-fold increase in $\mathrm{MIC}_{50} \mathrm{~s}$ values, and an 8-fold increase in $\mathrm{MIC}_{90} \mathrm{~s}$.

Table 1. Antibacterial summary of select chrysophaentins and synthetic fragments against five diverse strains of Staphylococcus aureus (all values are in $\mu \mathrm{M}$; n.d. means not determined).

\begin{tabular}{|c|c|c|c|c|c|c|c|c|c|c|c|c|c|c|}
\hline & \multicolumn{3}{|c|}{ S. aureus 25923} & \multicolumn{3}{|c|}{ MRSA BAA-41 } & \multicolumn{2}{|c|}{ MDRSA BAA-44 } & \multicolumn{3}{|c|}{ S. aureus UAMS-1 } & \multicolumn{3}{|c|}{$\begin{array}{c}\text { CA-MRSA } \\
\text { USA300-LAC }\end{array}$} \\
\hline & $\mathrm{MIC}_{50}$ & $\mathrm{MIC}_{90}$ & $\mathrm{MBC}$ & $\mathrm{MIC}_{50}$ & $\mathrm{MIC}_{90}$ & $\mathrm{MBC}$ & $\mathrm{MIC}_{50}$ & $\mathrm{MIC}_{90}$ & $\mathrm{MIC}_{50}$ & $\mathrm{MIC}_{90}$ & $\mathrm{MBC}$ & $\mathrm{MIC}_{50}$ & $\mathrm{MIC}_{90}$ & $\mathrm{MBC}$ \\
\hline 1 & $2.7 \pm 0.9$ & 9.2 & 37 & $2.3 \pm 1.0$ & 4.6 & 37 & $1.8 \pm 0.5$ & 9.2 & $5.1 \pm 2.1$ & 9.2 & 19 & $5.0 \pm 2.4$ & 9.2 & 19 \\
\hline 4 & $37 \pm 16$ & 65 & n.d. & $26 \pm 8.5$ & 65 & n.d. & n.d. & n.d. & $49 \pm 23$ & 65 & $>65$ & $41 \pm 20$ & 65 & $>65$ \\
\hline 5 & $16 \pm 5.3$ & 37 & 74 & $14 \pm 4.1$ & 37 & 74 & n.d. & n.d. & n.d. & n.d. & n.d. & n.d. & n.d. & n.d. \\
\hline 8 & $7.9 \pm 2.9$ & 19 & 74 & $6.3 \pm 1.9$ & 19 & 74 & n.d. & n.d. & $12 \pm 5.6$ & 37 & $>74$ & $12 \pm 5.1$ & 37 & 74 \\
\hline 9 & $23 \pm 7.5$ & 69 & n.d. & $17 \pm 4.3$ & 69 & n.d. & n.d. & n.d. & n.d. & n.d. & n.d. & n.d. & n.d. & n.d. \\
\hline 10 & $5.9 \pm 1.8$ & 17 & n.d. & $6.2 \pm 1.9$ & 17 & n.d. & n.d. & n.d. & n.d. & n.d. & n.d. & n.d. & n.d. & n.d. \\
\hline 11 & $12 \pm 4.3$ & 34 & 68 & $11 \pm 5.4$ & 34 & 68 & $13 \pm 4.7$ & 34 & $20 \pm 10$ & 34 & 68 & $18 \pm 8.4$ & 34 & 68 \\
\hline 12 & $20 \pm 5.2$ & 74 & 150 & $23 \pm 9.9$ & 74 & 150 & $27 \pm 9.4$ & 74 & $31 \pm 13$ & 74 & 150 & $29 \pm 9.9$ & 74 & 150 \\
\hline
\end{tabular}

\subsubsection{Antibacterial Activity of Synthetic Chrysophaentin Fragments}

We were gratified to find that compound 11 inhibited the growth of $S$. aureus 25923 with $\mathrm{MIC}_{50}$ and $\mathrm{MIC}_{90}$ values comparable to those for the linear and symmetrically linked natural products $\mathbf{5}$ and $\mathbf{8}$ (Table 1). At the $\mathrm{MIC}_{90}$, compound 11 was bacteriostatic, and its $\mathrm{MBC}$ was $68 \mu \mathrm{M}$. Compound 11 also inhibited the growth of MRSA BAA-41 and MDRSA BAA-44 with low micromolar $\mathrm{MIC}_{50}$, and an 
$\mathrm{MIC}_{90}$ of $34 \mu \mathrm{M}$ for both strains. Compound 12 was slightly less active with $\mathrm{MIC}_{50} \mathrm{~S}$ in the range of 20-28 $\mu \mathrm{M}$ against $S$. aureus 25923, MRSA BAA-41, and MDRSA BAA-44. An increase to $74 \mu \mathrm{M}$ in $\mathrm{MIC}_{90}$ was observed for all three strains. Compound 12 was bacteriostatic at this concentration, with a $\mathrm{MBC}$ of $\sim 150 \mu \mathrm{M}$.

\subsubsection{Antibacterial Activity against $S$. aureus UAMS-1 and CA-MRSA USA300-LAC}

Given the notable antibacterial activity observed for diverse laboratory strains of $S$. aureus, we were interested to compare the effects of several representative compounds on the clinical $S$. aureus strains UAMS-1 and CA-MRSA USA300-LAC. Compounds evaluated included chrysophaentins A, D, and F, and synthetic compounds 11 and $\mathbf{1 2}$, and $\mathrm{MIC}_{50}, \mathrm{MIC}_{90}$ and $\mathrm{MBC}$ values were determined for each compound. Chrysophaentin A was again the most potent, with an $\mathrm{MIC}_{50}$ of $5 \mu \mathrm{M}$ for both clinical strains (Table 1), and the $\mathrm{MIC}_{90}$ was only slightly higher at $9 \mu \mathrm{M}$. Chrysophaentin A was still bacteriostatic at low micromolar concentrations, and the MBC was only 2 times higher at $19 \mu \mathrm{M}$. By comparison, the symmetrical chrysophaentin $\mathrm{F}(\mathbf{8})$ was slightly less active with respective $\mathrm{MIC}_{50}$ and $\mathrm{MIC}_{90}$ values of 12 and $37 \mu \mathrm{M}$, and was also bacteriostatic at the $\mathrm{MIC}_{90}$. The $\mathrm{MIC}_{50}$ s for compounds 11 and 12 were similar to those of $\mathbf{8}$ as was the $\mathrm{MIC}_{90}$ for compound 11, while the $\mathrm{MIC}_{90}$ for compound 12 was higher. For both synthetic compounds, the MBC was two-fold higher than the $\mathrm{MIC}_{90}$. Finally, chrysophaentin D (4) was the least active with $\mathrm{MIC}_{50}$ s between 41 and $49 \mu \mathrm{M}$, and $\mathrm{MIC}_{90}$ s at $65 \mu \mathrm{M}$.

Growth curves for chrysophaentins A (1), D (4), and F (8), and compound 12 were graphed as percentage growth of untreated bacteria for S. aureus UAMS-1 (Figure 5A) and CA-MRSA USA300-LAC (Figure 5B). These curves clearly demonstrate the relationship between the structure of the chrysophaentins and analogs, halogen composition, and anti-staphylococcal activity.

Figure 5. Dose-response curves show the antibacterial activities and reveal a structure-activity relationship for the chrysophaentins. Chrysophaentins A (1), D (4), and F (8), and fragment 12 were tested for their ability to inhibit the growth of Staphylococcus aureus UAMS-1 (panel A) and CA-MRSA USA300-LAC (panel B) in a microbroth dilution assay. Plots represent percentage bacterial growth as a function of compound concentration.

A

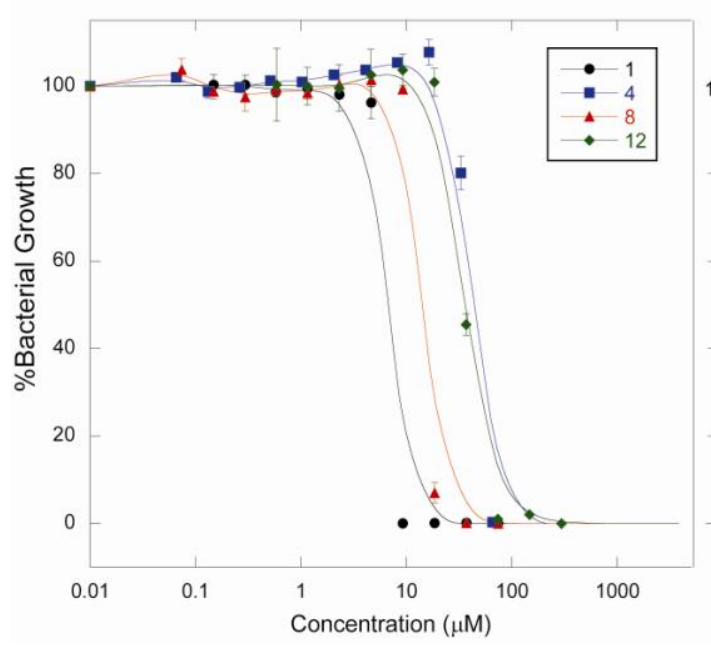

B

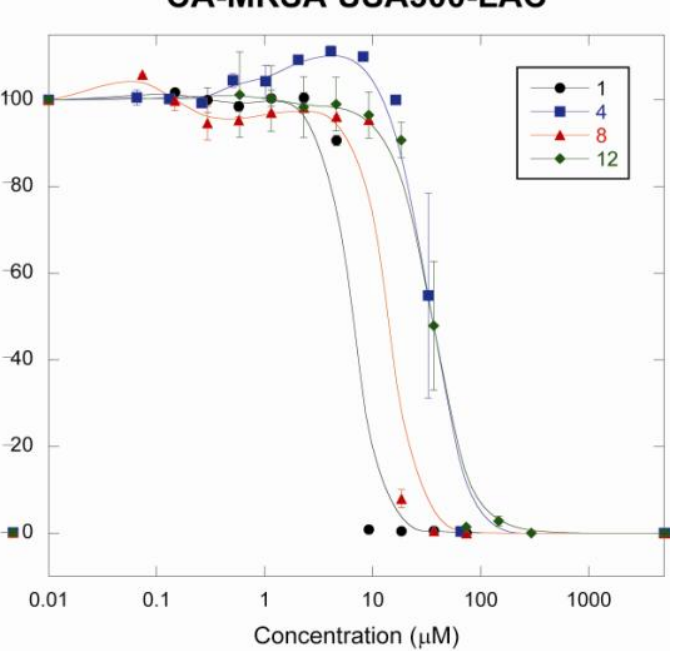




\subsection{Discussion}

C. taylori is a rare marine chrysophyte alga. It was originally discovered in the Dry Tortugas off the southern coast of Florida [40], and has since been found in several locations worldwide. Bioactive natural products have been discovered from collections made in two locations. The Puerto Rico location yielded hormothamnione [41] and 6-desmethoxyhormothamnione [42], while the collections from St. John, U.S. Virgin Islands have yielded the ten chrysophaentins, as well as hormothamnione and 6-methoxyhormothamnione. As we have described here, analysis of methanol extracts revealed geographic variability within the $C$. taylori collections from St. John. The original collection coming from Round Bay in 2007 yielded chrysophaentins A-H. A second collection at Round Bay two years later contained a similar profile of compounds, indicating temporal stability in the natural compound production at this location. A 2009 collection at Long Bay contained the same eight chrysophaentins in a similar ratio. Both Long Bay and Round Bay are on the southeastern side of the island, and each of these collections was made in shallow protected waters, where the algae were growing on coral sand. The 2009 collection from Hawk's Nest on the northwestern side of the island yielded a different profile of compounds. It was immediately obvious when comparing the chromatograms that the difference laid in the complete absence of the asymmetrical chrysophaentins in the samples collected at this location. Instead, the most abundant compounds included the acyclic chrysophaentin E, as well as two newly identified linear chrysophaentins, namely chrysophaentins E2 and E3.

Synthetic efforts to obtain a steady supply of chrysophaentin A are under way. An early approach that was employed provided two chrysophaentin fragments that we have shown exhibit similar potencies and spectrum of activity to those of the parent chrysophaentins. Previously, we profiled the anti-staphylococcal activity of several of the natural chrysophaentins towards common laboratory strains of $S$. aureus. In this study, we sought to expand the structure-activity relationship (SAR) by including the synthetic fragments, and to expand the number and diversity of $S$. aureus strains. We tested select compounds against five $S$. aureus strains to measure their potency $\left(\mathrm{MIC}_{50}\right.$ and $\left.\mathrm{MIC}_{90}\right)$ and to determine whether the compounds were bacteriostatic or bactericidal. All chrysophaentins, natural and synthetic, were bacteriostatic at their $\mathrm{MIC}_{90}$; but were bactericidal at concentrations ranging from two to eight fold higher than their respective $\mathrm{MIC}_{90}$ s. Furthermore, the synthetic fragments showed similar potency to the acyclic chrysophaentin E (5).

The synthetic fragments fit perfectly into our proposed structure-activity relationship. The tetrachlorinated macrocycle with the asymmetrical linkage between C-16 and C-1' (chrysophaentin A) was essential for maximum potency. Compounds with an ether bond between $\mathrm{C}-14$ and $\mathrm{C}-1^{\prime}$, which lead to a symmetrical macrocycle as seen in chrysophaentin $\mathrm{F}$, show a decrease in overall potency. The presence of a fifth halogen at C-12' did not decrease the antibacterial activity, even when the additional halogen was a bromine, indicating that the atom type at this position or even this ring is not critical to the observed activity. The absence of a macrocyclic structure, as in chrysophaentin $\mathrm{E}$ and the synthetic fragments 11 and 12, further decreased antibacterial activity. However, the presence of the asymmetrical macrocycle did not guarantee potency as halogen diversity on the phenyl rings also affected activity. Chrysophaentin D, which contains two bromines in place of the chlorines on the phenol rings in $\mathbf{1}$, was the least active compound considered in this study. 
We have shown that subtle changes to the chrysophaentin structure and composition lead to differences in antibacterial activity. Knowing that the macrocycle is essential for full antibacterial potency, it is not surprising that the synthetic fragments described here have diminished activity compared to the cyclic natural products. However, we were gratified to find that they are indeed antimicrobial and their activities are comparable to the linear chrysophaentins. Their ease of synthesis and antimicrobial activity provide an excellent starting point not only toward the cyclic chrysophaentins, but also for generating more elaborate synthetic analogs.

The biosynthetic pathway leading to production of the chrysophaentins has not been characterized and a genome sequence for any Chrysophaeum species has yet to be published. Interestingly, the most closely related natural products include the marchantins, bazzanins, and chlorinated isoplagiochins, all of which were isolated from different species of liverworts [43]. While these macrocyclic compounds are reminiscent of the chrysophaentins, each family possesses defining structural characteristics that differ relative to one another and to the chrysophaentins. The marchantins [44] are bisbibenzyl ethers whose phenol rings are connected by an ethyl group, and thus far do not contain halogens. The bazzanins [45,46] and chlorinated isoplagiochins [47], on the other hand are chlorinated, but are bisbibenzyls rather than bisbibenzyl ethers. Like the marchantins and all liverwort metabolites, they also contain ethyl linkages. The presence of a butene linkage is unique to the chrysophaentins. While some information is known about the biosynthesis of the liverwort metabolites [48], the pathways are incompletely characterized; moreover, parallels to chrysophaentin biosynthesis cannot be predicted as the producing organisms are not closely related. The lack of biosynthetic information underlines the importance of a synthetic approach that could supply large quantities of the chrysophaentins for further biological studies.

\section{Experimental Section}

\subsection{Biological Material}

Samples of the marine algae were collected from Round Bay in July 2007, and Long Bay, Round Bay, and Hawk's Nest in June 2009, St. John, U.S. Virgin Islands (Collection permit VIIS-2008-SCI-0034 National Park Service). Each of the alga samples were observed as fluffy, sulfur yellow colonies growing on coarse sand at shallow depths averaging $-20 \mathrm{ft}$. The samples were identified as Chrysophaeum taylori Lewis and Bryan as described previously [27]. Briefly, the presence of clear stalk like structures made up of branching mucilaginous "streamers" of pear shaped, invaginated cells were visible by light microscopy (4-10x) on freshly collected specimens, as well as those preserved in $2.5 \%$ glutaraldehyde in sterile sea water immediately after collection.

\section{2. $L C-M S$}

Lyophilized material was sequentially extracted with hexanes, $\mathrm{CH}_{2} \mathrm{Cl}_{2}$, and $\mathrm{MeOH}$. The $\mathrm{MeOH}$ extract was analyzed by reverse-phase HPLC with an MS detector (Jupiter Proteo C12, $250 \times 4.6 \mathrm{~mm}$, $4 \mu \mathrm{m}, \mathrm{DAD}$ at 220 and $280 \mathrm{~nm}$, flow rate $0.5 \mathrm{~mL} / \mathrm{min}$ ) eluting with a linear gradient of $50-80 \%$ methanol in $0.05 \%$ TFA-water in $50 \mathrm{~min}$. 


\subsection{Mass Spectrometry and MS/MS Fragmentation}

The $\mathrm{MeOH}$ extract was partitioned between $n-\mathrm{BuOH}-\mathrm{H}_{2} \mathrm{O}(1: 1)$, and the organic layer was fractionated on Sephadex LH-20. Fractions containing the unknown chrysophaentins were subjected to HR-ESI-MS and MS in-source fragmentation. High resolution accurate mass data was obtained using a Waters LCT Premiere ESI-TOF mass spectrometer equipped with a Z-Spray electrospray ion source. The instrument was operated in the w-mode at a nominal resolution of 10,000 and an internal standard was used as reference. The ionization mode was negative ion and the ESI capillary voltage was $-3000 \mathrm{~V}$ and the cone voltage was $30 \mathrm{~V}$. The collisionally activated dissociation (CAD) mass spectra were obtained using a Waters LCT Premiere ESI-TOF mass spectrometer according to the method described by Ren et al. [49] The ion guide 1 voltage was $65 \mathrm{~V}$ and the cone voltage was $30 \mathrm{~V}$. The instrument was operated in negative ion mode.

\subsection{General Synthesis}

All moisture sensitive reactions were performed using syringe-septum techniques under an atmosphere of either dry $\mathrm{N}_{2}$ or dry argon unless otherwise noted. All glassware was dried in an oven at $140{ }^{\circ} \mathrm{C}$ for a minimum of $6 \mathrm{~h}$ or flame-dried under an atmosphere of dry nitrogen prior to use. Reactions carried out at $-78{ }^{\circ} \mathrm{C}$ employed a $\mathrm{CO}_{2(\mathrm{~s})} /$ acetone bath. $\mathrm{Et}_{2} \mathrm{O}$ and tetrahydrofuran were dried by distillation over sodium/benzophenone under an argon atmosphere. Dry methylene chloride was purified by filtration through an activated alumina column. All degassed solvents were prepared using the freeze/pump/thaw method (3x). Methanol, acetonitrile, and $N, N$-dimethylformamide were stored over molecular sieves ( $3 \AA$ ). Deuterated chloroform was stored over anhydrous potassium carbonate. Reactions were monitored by TLC analysis (pre-coated silica gel $60 \mathrm{~F}_{254}$ plates, $250 \mu \mathrm{m}$ layer thickness) and visualized by using UV lamp $(254 \mathrm{~nm}$ ) or by staining with either Vaughn's reagent (4.8 $\mathrm{g}$ of $\left(\mathrm{NH}_{4}\right)_{6} \mathrm{Mo}_{7} \mathrm{O}_{24} \cdot 4 \mathrm{H}_{2} \mathrm{O}$ and $0.2 \mathrm{~g}$ of $\mathrm{Ce}\left(\mathrm{SO}_{4}\right)_{2}$ in $100 \mathrm{~mL}$ of a $\left.3.5 \mathrm{~N} \mathrm{H}_{2} \mathrm{SO}_{4}\right)$ or a potassium permanganate solution ( $1.5 \mathrm{~g}$ of $\mathrm{KMnO}_{4}$ and $1.5 \mathrm{~g}$ of $\mathrm{K}_{2} \mathrm{CO}_{3}$ in $100 \mathrm{~mL}$ of a $0.1 \% \mathrm{NaOH}$ solution). Flash column chromatography was performed with 40-63 $\mu \mathrm{m}$ silica gel (Silicycle). Microwave reactions were performed on a Biotage Initiator microwave reactor. Infrared spectra were measured on a Smiths Detection IdentifyIR FT-IR spectrometer (ATR). Unless otherwise indicated, all NMR data were collected at room temperature in $\mathrm{CDCl}_{3}$ or $\left(\mathrm{CD}_{3}\right)_{2} \mathrm{CO}$ on a $300,400,500,600$, or $700 \mathrm{MHz}$ Bruker instrument. Chemical shifts $(\delta)$ are reported in parts per million $(\mathrm{ppm})$ with internal $\mathrm{CHCl}_{3}(\delta 7.26 \mathrm{ppm}$ for ${ }^{1} \mathrm{H}$ and $77.00 \mathrm{ppm}$ for ${ }^{13} \mathrm{C}$ ), or internal acetone ( $\delta 2.05 \mathrm{ppm}$ for ${ }^{1} \mathrm{H}$ and $29.85 \mathrm{ppm}$ for ${ }^{13} \mathrm{C}$ ), as the reference. ${ }^{1} \mathrm{H}$ NMR data are reported as follows: chemical shift, multiplicity ( $\mathrm{s}=$ singlet, bs = broad singlet, $\mathrm{d}=$ doublet, $\mathrm{t}=$ triplet, $\mathrm{q}=$ quartet, $\mathrm{m}=$ multiplet, $\mathrm{dd}=$ doublet of doublets, $\mathrm{dt}=$ doublet of triplets, $\mathrm{td}=$ triplet of doublets, $\mathrm{qd}=$ quartet of doublets, sep = septet), integration, and coupling constant(s) $(J)$ in Hertz $(\mathrm{Hz})$.

3,5-Dimethoxy benzyl alcohol (18) [29]. To a stirred suspension of lithium aluminum hydride (13.1 g, $329 \mathrm{mmol}, 2$ equiv) in dry $\mathrm{THF}(400 \mathrm{~mL})$ at $0{ }^{\circ} \mathrm{C}$ was added a solution of 3,5-dimethoxybenzoic acid ( $30.0 \mathrm{~g}, 164 \mathrm{mmol}, 1$ equiv) in dry THF (400 mL) over $45 \mathrm{~min}$. Upon completion of the addition, the reaction mixture was diluted with THF $(300 \mathrm{~mL})$, warmed to rt, stirred for $5 \mathrm{~h}$, and slowly quenched with a saturated aqueous solution of $\mathrm{Na} / \mathrm{K}$ tartrate. The resulting biphasic mixture was stirred at r.t. for 
$1 \mathrm{~h}$, the organic layer was separated, the remaining aqueous layer was extracted with EtOAc $(\times 2)$, and the combined organic layers were dried $\left(\mathrm{MgSO}_{4}\right)$, filtered, and concentrated under reduced pressure to give $27.0 \mathrm{~g}(97 \%)$ of $\mathbf{1 8}$ as a colorless oil: Rf 0.33 (EtOAc/hexanes, 1:2); IR ( $\left.\mathrm{CDCl}_{3}\right)$ 3390, 2937, 1594, 1456, 1428, 1318, 1294, 1202, 1146, 1057, $829 \mathrm{~cm}^{-1} ;{ }^{1} \mathrm{H}$ NMR $\left(600 \mathrm{MHz}, \mathrm{CDCl}_{3}\right) \delta_{\mathrm{H}} 6.45$ $(\mathrm{d}, 2 \mathrm{H}, J=2.4 \mathrm{~Hz}), 6.32(\mathrm{~d}, 1 \mathrm{H}, J=2.4 \mathrm{~Hz}), 4.50(\mathrm{~d}, 2 \mathrm{H}, J=5.4 \mathrm{~Hz}), 3.71(\mathrm{~s}, 6 \mathrm{H}), 3.49(\mathrm{t}, 1 \mathrm{H}$, $J=5.4 \mathrm{~Hz}) ;{ }^{13} \mathrm{C}$ NMR $\left(150 \mathrm{MHz}, \mathrm{CDCl}_{3}\right) \delta_{\mathrm{C}} 160.5,143.3,104.2,99.2$, 64.5, 55.0.

3,5-Dimethoxybenzyl bromide (19) [29]. To a stirred solution of $\mathbf{1 8}$ (17.5 g, 104 mmol, 1 equiv) in $\mathrm{CH}_{2} \mathrm{Cl}_{2}(500 \mathrm{~mL})$ at $0{ }^{\circ} \mathrm{C}$ was added dropwise $\mathrm{PBr}_{3}(12.1 \mathrm{~mL}, 125 \mathrm{mmol}, 1.2$ equiv). The reaction mixture was slowly warmed to rt, stirred for $3 \mathrm{~h}$, quenched with a saturated aqueous solution of $\mathrm{NaHCO}_{3}$, and stirred at r.t. for $1 \mathrm{~h}$. The organic layer was separated and the aqueous layer was extracted with $\mathrm{Et}_{2} \mathrm{O}$. The combined organic layers were dried $\left(\mathrm{MgSO}_{4}\right)$, filtered, and concentrated under reduced pressure to give $22.2 \mathrm{~g}$ (92\%) of $\mathbf{1 9}$ as a white solid: Rf 0.75 (EtOAc/hexanes, 1:2); IR $\left(\mathrm{CDCl}_{3}\right)$ 2999, 2954, 1596, 1458, 1428, 1345, 1323, 1297, 1204, 1152, 1062, $930 \mathrm{~cm}^{-1} ;{ }^{1} \mathrm{H}$ NMR $\left(400 \mathrm{MHz}, \mathrm{CDCl}_{3}\right) \delta_{\mathrm{H}} 6.54(\mathrm{~d}, 2 \mathrm{H}, J=2.0 \mathrm{~Hz}), 6.39(\mathrm{~d}, 1 \mathrm{H}, J=2.4 \mathrm{~Hz}), 4.42(\mathrm{~s}, 2 \mathrm{H}), 3.80(\mathrm{~s}, 6 \mathrm{H})$; ${ }^{13} \mathrm{C} \mathrm{NMR}\left(150 \mathrm{MHz}, \mathrm{CDCl}_{3}\right) \delta_{\mathrm{C}} 160.9,139.7,107.0,100.6,55.4,33.6$; HRMS $\left(\mathrm{ESI}^{+}\right) \mathrm{m} / \mathrm{z}$ calcd for $\mathrm{C}_{9} \mathrm{H}_{12} \mathrm{O}_{2} \mathrm{Br} 231.0021$, found 231.0038.

(3-(3,5-Dimethoxyphenyl)prop-1-ynyl)trimethylsilane (20). To a stirred solution of ethynyl trimethysilane $\left(39.1 \mathrm{~mL}, 277 \mathrm{mmol}, 4\right.$ equiv) in THF $(120 \mathrm{~mL})$ at $0{ }^{\circ} \mathrm{C}$ was added ethylmagnesium bromide (3.16 $\mathrm{M}$ in $\mathrm{Et}_{2} \mathrm{O} ; 87.6 \mathrm{~mL}, 277 \mathrm{mmol}, 4$ equiv). The reaction was warmed to rt, stirred for $30 \mathrm{~min}$, and $\mathrm{CuBr}$ (9.93 g, $69.2 \mathrm{mmol}, 1$ equiv) was added. The reaction was stirred at r.t. for $15 \mathrm{~min}$, 3,5-dimethoxybenzyl bromide (19, $16.0 \mathrm{~g}, 69.2 \mathrm{mmol}, 1$ equiv) was added, the resulting mixture was heated to $66{ }^{\circ} \mathrm{C}$, and stirred overnight. The reaction mixture was diluted with $\mathrm{Et}_{2} \mathrm{O}$, slowly quenched with brine, and extracted with $\mathrm{Et}_{2} \mathrm{O}(\times 2)$. The combined organic layers were washed with a saturated aqueous solution of $\mathrm{NH}_{4} \mathrm{Cl}$, brine, dried $\left(\mathrm{MgSO}_{4}\right)$, filtered, and concentrated under reduced pressure. The crude mixture was purified by chromatography on $\mathrm{SiO}_{2}$ (EtOAc/hexanes, 1:10) to give $17.2 \mathrm{~g}$ (100\%) of $\mathbf{2 0}$ as a pale yellow oil: Rf 0.41 (EtOAc/hexanes, 1:20); IR (neat) 2956, 2898, 2175, 1754, 1596, 1459, 1428, 1204, 1156, 1122, 1101, $839 \mathrm{~cm}^{-1} ;{ }^{1} \mathrm{H}$ NMR $\left(400 \mathrm{MHz}, \mathrm{CDCl}_{3}\right) \delta_{\mathrm{H}} 6.53(\mathrm{~d}, 2 \mathrm{H}$, $J=2.4 \mathrm{~Hz}), 6.34(\mathrm{t}, 1 \mathrm{H}, J=2.4 \mathrm{~Hz}), 3.79(\mathrm{~s}, 6 \mathrm{H}), 3.60(\mathrm{~s}, 2 \mathrm{H}), 0.19(\mathrm{~s}, 9 \mathrm{H}) ;{ }^{13} \mathrm{C} \mathrm{NMR}(100 \mathrm{MHz}$, $\left.\mathrm{CDCl}_{3}\right) \delta_{\mathrm{C}} 160.8,138.7,105.9,104.0,98.7,87.1,55.3,26.3,0.1$; HRMS $\left(\mathrm{ESI}^{+}\right) \mathrm{m} / \mathrm{z}$ calcd for $\mathrm{C}_{14} \mathrm{H}_{21} \mathrm{O}_{2} \mathrm{Si} 249.1311$, found 249.1287.

1,3-Dimethoxy-5-(prop-2-ynyl)benzene (15). To a stirred solution of 20 (5.37 g, 21.6 mmol, 1 equiv) and $\mathrm{AcOH}$ (4.99 mL, $86.5 \mathrm{mmol}, 4$ equiv) in THF (100 mL) was added dropwise TBAF (1 M in THF; $86.5 \mathrm{~mL}, 86.5 \mathrm{mmol}, 4$ equiv). The resulting reaction mixture was stirred at r.t. for $24 \mathrm{~h}$, diluted with $\mathrm{Et}_{2} \mathrm{O}$, washed with brine $(\times 2)$, dried $\left(\mathrm{MgSO}_{4}\right)$, filtered, and concentrated under reduced pressure. The crude mixture was purified by chromatography on $\mathrm{SiO}_{2}$ (EtOAc/hexanes, 1:10) to give $3.85 \mathrm{~g}$ (100\%) of $\mathbf{1 5}$ as a colorless oil: Rf 0.36 (EtOAc/hexanes, 1:10); IR $\left(\mathrm{CDCl}_{3}\right)$ 3286, 2999, 2954, 1593, 1457, 1428, 1344, 1323, 1288, 1204, 1154, 1064, 827; ${ }^{1} \mathrm{H}$ NMR (400 MHz, $\left.\mathrm{CDCl}_{3}\right) \delta_{\mathrm{H}} 6.53(\mathrm{~d}, 2 \mathrm{H}$, $J=2.4 \mathrm{~Hz}), 6.35(\mathrm{t}, 1 \mathrm{H}, J=2.4 \mathrm{~Hz}), 3.79(\mathrm{~s}, 6 \mathrm{H}), 3.56(\mathrm{~d}, 2 \mathrm{H}, J=2.8 \mathrm{~Hz}), 2.20(\mathrm{t}, 1 \mathrm{H}, J=2.8 \mathrm{~Hz})$; ${ }^{13} \mathrm{C} \mathrm{NMR}\left(100 \mathrm{MHz}, \mathrm{CDCl}_{3}\right) \delta_{\mathrm{C}} 160.9,138.3,105.9,98.7,81.7,70.6,55.3,25.0$; HRMS $\left(\mathrm{EI}^{+}\right)$ $m / z$ calcd for $\mathrm{C}_{11} \mathrm{H}_{12} \mathrm{O}_{2}$ 176.0837, found 176.0834 . 
5-(Prop-2-ynyl)-1,3-phenylene bis(2,2-dimethylpropanoate (21). To a stirred solution of 15 (6.50 g, 36.9 mmol, 1 equiv) in $\mathrm{CH}_{2} \mathrm{Cl}_{2}(1200 \mathrm{~mL})$ at $0{ }^{\circ} \mathrm{C}$ was added $\mathrm{BBr}_{3}\left(1 \mathrm{M}\right.$ in $\mathrm{CH}_{2} \mathrm{Cl}_{2} ; 92.2 \mathrm{~mL}$, $92.2 \mathrm{mmol}, 5$ equiv) over $1 \mathrm{~h}$ via an addition funnel. The reaction mixture was warmed to r.t. and stirred overnight. The reaction mixture was slowly quenched with a saturated aqueous solution of $\mathrm{NaHCO}_{3}(500 \mathrm{~mL})$ and stirred at r.t. for $4 \mathrm{~h}$. The solution was acidified with $\mathrm{HCl}$, extracted with $\mathrm{CH}_{2} \mathrm{Cl}_{2}$ and EtOAc, and the combined organic layers were dried $\left(\mathrm{MgSO}_{4}\right)$, filtered, and concentrated under reduced pressure. The crude mixture was dissolved in $\mathrm{CH}_{2} \mathrm{Cl}_{2}(180 \mathrm{~mL})$, and triethylamine (20.9 mL, $148 \mathrm{mmol}, 4$ equiv) and $\mathrm{PivCl}$ (11.6 mL, $92.2 \mathrm{mmol}, 2.5$ equiv) were added. The resulting solution was stirred at r.t. for $90 \mathrm{~min}$, diluted with brine, the organic layer was separated, and the aqueous layer was extracted with EtOAc. The combined organic layers were dried $\left(\mathrm{MgSO}_{4}\right)$, filtered, and concentrated under reduced pressure. The crude mixture was purified by chromatography on $\mathrm{SiO}_{2}$ (EtOAc/hexanes, 1:10) to give $9.6 \mathrm{~g}$ (82\%) of $\mathbf{2 1}$ as a colorless oil: Rf 0.85 (EtOAc/hexanes, 3:7); IR (neat) 3293, 2973, 1806, 1750, 1414, 1452, 1396, 1366, 1269, 1118, 1098, 1031, $1003 \mathrm{~cm}^{-1}$; ${ }^{1} \mathrm{H}$ NMR $\left(300 \mathrm{MHz}, \mathrm{CDCl}_{3}\right) \delta_{\mathrm{H}} 6.95(\mathrm{~d}, 2 \mathrm{H}, J=1.8 \mathrm{~Hz}), 6.76(\mathrm{t}, 1 \mathrm{H}, J=1.8 \mathrm{~Hz}), 3.61(\mathrm{~d}, 2 \mathrm{H}$, $J=2.4 \mathrm{~Hz}), 2.21(\mathrm{t}, 1 \mathrm{H}, J=2.4 \mathrm{~Hz}) ;{ }^{13} \mathrm{C} \mathrm{NMR}\left(75 \mathrm{MHz}, \mathrm{CDCl}_{3}\right) \delta_{\mathrm{C}} 176.6,151.5,138.3,118.3,113.8$, 80.7, 71.2, 39.1, 27.1, 24.5; HRMS $\left(\mathrm{EI}^{+}\right) \mathrm{m} / \mathrm{z}$ c calcd for $\mathrm{C}_{19} \mathrm{H}_{24} \mathrm{O}_{4} 316.1675$, found 316.1670 .

4-Chloro-2,5-dimethoxybenzaldehyde (16) [33,34]. To a stirred solution of 2-chloro-1,4-dimethoxy benzene (25.0 g, $0.145 \mathrm{~mol}, 1$ equiv) and hexamethylene tetramine (20.5 g, $0.145 \mathrm{~mol}, 1$ equiv) at r.t. was carefully added TFA $(250 \mathrm{~mL})$. The resulting yellow suspension was heated to $95{ }^{\circ} \mathrm{C}$, stirred for $5 \mathrm{~h}$, and the hot brown solution was poured into a 2 L Erlenmeyer flask containing approximately $250 \mathrm{~g}$ of crushed ice. To the vigorously stirred mixture was slowly added solid $\mathrm{NaHCO}_{3}(243 \mathrm{~g}$, 2.90 mol, 20 equiv) in 5-10 g portions over two hours. The resulting yellow precipitate was filtered through a pad of celite, washed with water, and dissolved in $\mathrm{Et}_{2} \mathrm{O}$. The organic layer was washed with water and brine, dried $\left(\mathrm{MgSO}_{4}\right)$, filtered, and concentrated under reduced pressure to yield $29.0 \mathrm{~g}$ (100\%) of $\mathbf{1 6}$ as an off-white solid: Rf 0.70 (EtOAc/hexanes, 3:7); IR (neat) 2941, 2874, 1664, 1601, 1575, 1497, 1478, 1461, 1389, 1269, 1213, 1023, $977 \mathrm{~cm}^{-1} ;{ }^{1} \mathrm{H}$ NMR $\left(400 \mathrm{MHz}, \mathrm{CDCl}_{3}\right) \delta_{\mathrm{H}} 10.35$ (s, $1 \mathrm{H}), 7.33(\mathrm{~s}, 1 \mathrm{H}), 7.03(\mathrm{~s}, 1 \mathrm{H}), 3.87(\mathrm{~s}, 6 \mathrm{H}) ;{ }^{13} \mathrm{C} \mathrm{NMR}\left(100 \mathrm{MHz}, \mathrm{CDCl}_{3}\right) \delta_{\mathrm{C}} 188.4,156.1,149.4$, 130.4, 123.4, 114.5, 109.9, 56.5, 56.3; HRMS $\left(\mathrm{EI}^{+}\right) \mathrm{m} / \mathrm{z}$ calcd for $\mathrm{C}_{9} \mathrm{H}_{9} \mathrm{O}_{3} \mathrm{Cl} 200.0240$, found 200.0238.

(4-Chloro-2,5-dimethoxyphenyl)methanol (25). To a stirred solution of 16 (29.0 g, $145 \mathrm{mmol}$, 1 equiv) in absolute ethanol $(550 \mathrm{~mL})$ was added sodium borohydride $(27.3 \mathrm{~g}, 723 \mathrm{mmol}, 5$ equiv). The reaction mixture was stirred at r.t. for $6 \mathrm{~h}$, quenched via dropwise addition of acetone, diluted with EtOAc, washed with brine $(\times 2)$, dried $\left(\mathrm{MgSO}_{4}\right)$, filtered, and concentrated under reduced pressure. The crude residue was purified by chromatography on $\mathrm{SiO}_{2}$ (EtOAc/hexanes, 1:1) to give $28.0 \mathrm{~g}$ (96\%) of 25 as a white solid: mp 89-90 ${ }^{\circ} \mathrm{C}$; Rf 0.53 (EtOAc/hexanes, 1:1); IR (neat) 3258, 2958, 2915, 1495, 1461, 1392, 1204, 1061, $719 \mathrm{~cm}^{-1}$; ${ }^{1} \mathrm{H}$ NMR $\left(300 \mathrm{MHz}, \mathrm{CDCl}_{3}\right) \delta_{\mathrm{H}} 6.90(\mathrm{~s}, 1 \mathrm{H}), 6.80(\mathrm{~s}, 1 \mathrm{H}), 4.55$ $(\mathrm{d}, 2 \mathrm{H}, J=4.2 \mathrm{~Hz}), 3.77(\mathrm{~s}, 3 \mathrm{H}), 3.71(\mathrm{~s}, 3 \mathrm{H}), 3.10(\mathrm{bs}, 1 \mathrm{H}) ;{ }^{13} \mathrm{C} \mathrm{NMR}\left(75 \mathrm{MHz}, \mathrm{CDCl}_{3}\right) \delta_{\mathrm{C}} 150.6$, 148.7, 128.4, 120.8, 112.5, 112.4, 60.3, 56.5, 55.6; HRMS $\left(\mathrm{ESI}^{+}\right) \mathrm{m} / \mathrm{z}$ calcd for $\mathrm{C}_{9} \mathrm{H}_{12} \mathrm{O}_{3} \mathrm{Cl} 203.0475$, found 203.0465 .

1-(Bromomethyl)-4-chloro-2,5-dimethoxybenzene (26) [50]. To a stirred solution of 25 (5.00 g, $24.7 \mathrm{mmol}, 1$ equiv) in $\mathrm{CH}_{2} \mathrm{Cl}_{2}\left(125 \mathrm{~mL}\right.$ ) at $0{ }^{\circ} \mathrm{C}$ was added dropwise $\mathrm{HBr}$ (47-49\% aqueous solution; $4.13 \mathrm{~mL}, 74.0 \mathrm{mmol}, 3$ equiv). The resulting solution was slowly warmed to r.t. and stirred overnight. 
The following morning a second batch of $\mathrm{HBr}(47-49 \%$ solution; $4.13 \mathrm{~mL}, 74.0 \mathrm{mmol}, 3$ equiv) was added to the reaction mixture, which was stirred at r.t. for an additional $4 \mathrm{~h}$, extracted with $\mathrm{Et}_{2} \mathrm{O}(\times 2)$, washed with water, a saturated aqueous solution of $\mathrm{NaHCO}_{3}$, brine, dried $\left(\mathrm{MgSO}_{4}\right)$, filtered, and concentrated under reduced pressure to give $6.55 \mathrm{~g}(100 \%)$ of $\mathbf{2 6}$ as a white solid: $\mathrm{Rf} 0.31$ (EtOAc/hexanes, 3:7); IR (neat) 2962, 2947, 2844, 1732, 1582, 1495, 1458, 1443, 1389, 1301, 1204, 1182, 1033, $882 \mathrm{~cm}^{-1} ;{ }^{1} \mathrm{H}$ NMR (400 MHz, $\left.\mathrm{CDCl}_{3}\right) \delta_{\mathrm{H}} 6.91-6.90(\mathrm{~m}, 2 \mathrm{H}), 4.50(\mathrm{~s}, 2 \mathrm{H}), 3.84(\mathrm{~s}, 3 \mathrm{H})$, $3.82(\mathrm{~s}, 3 \mathrm{H}) ;{ }^{13} \mathrm{C} \mathrm{NMR}\left(75 \mathrm{MHz}, \mathrm{CDCl}_{3}\right) \delta_{\mathrm{C}} 151.3,148.9,125.1,123.2,114.6,113.6,56.6,56.2,28.2$.

(E)-5-(2-Chloro-3-iodoallyl)-1,3-phenylene bis(2,2-dimethylpropanoate (22) and (Z)-5-(2-Chloro3-iodoallyl)-1,3-phenylene bis(2,2-dimethylpropanoate (23). To a stirred solution of 21 (9.50 g, $30.0 \mathrm{mmol}, 1$ equiv) in dry $\mathrm{CH}_{2} \mathrm{Cl}_{2}(150 \mathrm{~mL})$ at $0{ }^{\circ} \mathrm{C}$ was added $\mathrm{ICl}\left(1 \mathrm{M}\right.$ in $\mathrm{CH}_{2} \mathrm{Cl}_{2} ; 30.0 \mathrm{~mL}$, $30.0 \mathrm{mmol}, 1$ equiv). The reaction mixture was warmed to $\mathrm{rt}$, stirred protected from light (enclosed in aluminum foil) for $3 \mathrm{~h}$, diluted with $\mathrm{Et}_{2} \mathrm{O}$, washed with $\mathrm{Na}_{2} \mathrm{SO}_{4}(\times 2)$, brine, dried $\left(\mathrm{MgSO}_{4}\right)$, filtered, and concentrated under reduced pressure. The crude mixture was purified by chromatography on $\mathrm{SiO}_{2}$ (EtOAc/hexanes, 1:10) to give an inseparable 2:1 mixture of 22 and 23 (13.7 g, 95\%) as a colorless oil: Rf 0.54 (EtOAc/hexanes, 1:10); IR (neat) 3277, 2934, 2872, 1746, 1592, 1497, 1461, 1409, 1269, 1207, 1122, 1103, 1032, 975, $723 \mathrm{~cm}^{-1}$; HRMS $\left(\mathrm{ESI}^{+}\right) \mathrm{m} / z$ calcd for $\mathrm{C}_{19} \mathrm{H}_{24} \mathrm{O}_{4} \mathrm{NaClI}$ 501.0306, found 501.0308. Characteristic data for the major, desired isomer 22: ${ }^{1} \mathrm{H}$ NMR $\left(300 \mathrm{MHz}, \mathrm{CDCl}_{3}\right) \delta_{\mathrm{H}} 6.87$ $(\mathrm{d}, 2 \mathrm{H}, J=1.5 \mathrm{~Hz}), 6.80(\mathrm{t}, 1 \mathrm{H}, J=2.1 \mathrm{~Hz}), 6.62(\mathrm{~s}, 1 \mathrm{H}), 3.90(\mathrm{~s}, 2 \mathrm{H}), 1.35(\mathrm{~s}, 18 \mathrm{H}) ;{ }^{13} \mathrm{C} \mathrm{NMR}$ $\left(100 \mathrm{MHz}, \mathrm{CDCl}_{3}\right) \delta_{\mathrm{C}} 176.6,151.6,137.9,135.6,119.0,114.2,74.8,44.2,39.1,27.1$. Characteristic signals for 23: ${ }^{1} \mathrm{H}$ NMR $\left(300 \mathrm{MHz}, \mathrm{CDCl}_{3}\right) \delta_{\mathrm{H}} 7.06(\mathrm{~s}, 1 \mathrm{H}), 3.92(\mathrm{~s}, 2 \mathrm{H})$.

(E)-5-(2-Chloro-4-(4-chloro-2,5-dimethoxyphenyl)but-2-enyl)benzene-1,3-diol (11). A flame-dried microwave vial was charged with a 2:1 mixture of 22 and $\mathbf{2 3}\left(0.520 \mathrm{~g}, 1.08 \mathrm{mmol}, 1\right.$ equiv), $\mathrm{Pd}(\mathrm{OAc})_{2}$ $(0.0122 \mathrm{~g}, 0.0543 \mathrm{mmol}, 0.05$ equiv $), \mathrm{P}(o \text {-tol })_{3}(0.0341 \mathrm{~g}(0.109 \mathrm{mmol}, 0.1$ equiv), and freshly distilled, dry, degassed DMF $(0.8 \mathrm{~mL})$. The reaction mixture was stirred at r.t. for $10 \mathrm{~min}$. In a separate dry flask, a catalytic amount of iodine ( $20 \mathrm{mg})$ and zinc $(0.362 \mathrm{~g}, 5.43 \mathrm{mmol}, 5$ equiv) were heated (bunsen burner) until a purple gas coated the interior of the flask. The flask was cooled to rt, charged with distilled, dry, degassed DMF (1 mL), and benzyl bromide 26 (1.15 g, 4.34 mmol, 4 equiv). The mixture was allowed to stir at r.t. under argon for $6 \mathrm{~min}$. The activated organozinc reagent was filtered through an oven dried fritted funnel under an atmosphere of argon and cannulated into the stirred solution of 22 and $\mathbf{2 3}$. The resulting solution was heated in a microwave reactor $\left(2 \mathrm{~min}, 120{ }^{\circ} \mathrm{C}\right.$ ), treated with a second batch of $\mathrm{Pd}(\mathrm{OAc})_{2}(0.0122 \mathrm{~g}, 0.0543 \mathrm{mmol}, 0.05$ equiv) and resubjected to the microwave conditions ( $2 \mathrm{~min}, 120{ }^{\circ} \mathrm{C}$ ). The crude reaction mixture was directly purified by chromatography on $\mathrm{SiO}_{2}$ (EtOAc/hexanes, 1:20) to give a crude yellow oil which was immediately dissolved in $\mathrm{MeOH} / \mathrm{CH}_{2} \mathrm{Cl}_{2}$ (4 mL, 2:1), and $\mathrm{Cs}_{2} \mathrm{CO}_{3}$ (1.67 g, $5.08 \mathrm{mmol}$, 5 equiv) was added. The reaction mixture was stirred at r.t. for $6 \mathrm{~h}$, diluted with EtOAc, and acidified with conc. $\mathrm{HCl}$. The organic layer was separated, and the acidified aqueous solution was extracted with EtOAc. The combined organic layers were washed with brine, dried $\left(\mathrm{MgSO}_{4}\right)$, filtered, and concentrated under reduced pressure. The crude mixture was purified by chromatography on $\mathrm{SiO}_{2}$ (chloroform/acetone, 8:2) to give a 2:1 mixture of $\mathbf{1 1}$ and the undesired regioisomer $27(0.192 \mathrm{~g}, 51 \%)$ as a yellow oil. Characteristic signals for 27: ${ }^{1} \mathrm{H}$ NMR $\left(600 \mathrm{MHz}\left(\mathrm{CD}_{3}\right)_{2} \mathrm{CO}\right) \delta_{\mathrm{H}} 8.20(\mathrm{bs}, 2 \mathrm{H}), 7.02(\mathrm{~d}, 2 \mathrm{H}, J=3.6 \mathrm{~Hz})$, $6.45(\mathrm{t}, 1 \mathrm{H}, J=7.8 \mathrm{~Hz}), 6.26(\mathrm{~s}, 3 \mathrm{H}), 3.84(\operatorname{app~s}, 5 \mathrm{H}), 3.81(\mathrm{~s}, 3 \mathrm{H}), 3.50(\mathrm{~d}, 2 \mathrm{H}, J=7.8 \mathrm{~Hz})$; 
${ }^{13} \mathrm{C} \mathrm{NMR}\left(150 \mathrm{MHz}, \mathrm{CDCl}_{3}\right) \delta_{\mathrm{C}} 159.5,152.3,150.0,141.5,140.7,127.7,120.9,115.6,113.8,108.1$, 101.9, 101.7, 56.9, 56.5, 45.1.

An analytically pure sample of $\mathbf{1 1}$ for biological evaluation and characterization was obtained via SFC chromatography using a semiprep $(250 \times 10 \mathrm{~mm})$ silica column (Rt $5.80 \mathrm{~min}, 10 \mathrm{~mL} / \mathrm{min}$, 15\% methanol, $220 \mathrm{~nm}$ detection): Rf 0.48 (acetone/chloroform, 2:8); IR (acetone) 3375, 3001, 2952, 1696, 1599, 1495, 1463, 1387, 1212, 1156, 1034, $1010 \mathrm{~cm}^{-1} ;{ }^{1} \mathrm{H}$ NMR $\left(600 \mathrm{MHz}\left(\mathrm{CD}_{3}\right)_{2} \mathrm{CO}\right) \delta_{\mathrm{H}} 8.18$ (bs, $2 \mathrm{H}), 7.02(\mathrm{~s}, 1 \mathrm{H}), 6.99(\mathrm{~s}, 1 \mathrm{H}), 6.30(\mathrm{~s}, 2 \mathrm{H}), 6.25(\mathrm{~s}, 1 \mathrm{H}), 5.88(\mathrm{t}, 1 \mathrm{H}, J=7.8 \mathrm{~Hz}), 3.84(\mathrm{~s}, 3 \mathrm{H})$, $3.81(\mathrm{~s}, 3 \mathrm{H}), 3.73(\mathrm{~s}, 2 \mathrm{H}), 3.51(\mathrm{~d}, 2 \mathrm{H}, J=7.8 \mathrm{~Hz}) ;{ }^{13} \mathrm{C} \mathrm{NMR}\left(150 \mathrm{MHz}, \mathrm{CDCl}_{3}\right) \delta_{\mathrm{C}} 159.5,152.3$, 150.0, 140.6, 133.7, 128.1, 128.1, 120.8, 115.5, 113.8, 108.0, 101.8, 56.9, 56.5, 40.2, 29.5; HRMS $\left(\mathrm{ES}^{-}\right)[\mathrm{M}+\mathrm{Cl}]^{-} \mathrm{m} / \mathrm{z}$ calcd for $\mathrm{C}_{18} \mathrm{H}_{18} \mathrm{O}_{4} \mathrm{Cl}_{3} 403.0271$, found 403.0295 .

(E)-5-(2-Chloro-4-(4-chloro-2,5-dihydroxyphenyl)but-2-enyl)benzene-1,3-diol (12). A stirred solution of $11\left(0.0500 \mathrm{~g}, 0.135 \mathrm{mmol}, 1\right.$ equiv) in $\mathrm{CH}_{2} \mathrm{Cl}_{2}(7 \mathrm{~mL})$ was enclosed in aluminum foil and cooled to $0{ }^{\circ} \mathrm{C}$. To the stirred solution was added dropwise $\mathrm{BBr}_{3}\left(1 \mathrm{M}\right.$ in $\mathrm{CH}_{2} \mathrm{Cl}_{2} ; 0.677 \mathrm{~mL}$, $0.677 \mathrm{mmol}, 5$ equiv). The resulting solution was slowly warmed to r.t. and stirred overnight. The reaction mixture was quenched with a saturated aqueous solution of $\mathrm{NaHCO}_{3}(8 \mathrm{~mL})$ and stirred at r.t. for an additional hour. The solution was acidified with $\mathrm{HCl}$, extracted with EtOAc $(\times 2)$ and the combined organic layers were dried $\left(\mathrm{MgSO}_{4}\right)$, filtered, and concentrated under reduced pressure. The crude product was purified by chromatography on $\mathrm{SiO}_{2}$ (chloroform/acetone, 3:1) to give $12(0.0462 \mathrm{~g}$, 96\%) as a slightly yellow film. Before submission for biological testing, a sample of $\mathbf{1 2}$ was further purified via SFC chromatography using a semiprep $(250 \times 10 \mathrm{~mm})$ silica column (Rt $4.68 \mathrm{~min}$, $8 \mathrm{~mL} / \mathrm{min}, 25 \%$ methanol, $220 \mathrm{~nm}$ detection): Rf 0.15 (acetone/chloroform, 2:8); IR (neat) 3343, 1692, 1599, 1495, 1417, 1329, 1184, 1143, 1005, $822 \mathrm{~cm}^{-1}$; ${ }^{1} \mathrm{H}$ NMR $\left(600 \mathrm{MHz}\left(\mathrm{CD}_{3}\right)_{2} \mathrm{CO}\right) \delta_{\mathrm{H}} 8.17$ (bs, $\left.4 \mathrm{H}\right)$, $6.86(\mathrm{~s}, 1 \mathrm{H}), 6.84(\mathrm{~s}, 1 \mathrm{H}), 6.29(\mathrm{~d}, 2 \mathrm{H}, J=2.4 \mathrm{~Hz}), 6.24(\mathrm{t}, 1 \mathrm{H}, J=2.4 \mathrm{~Hz}), 5.89$ (t, $1 \mathrm{H}, J=7.8 \mathrm{~Hz})$, 3.69 (s, $2 \mathrm{H}), 3.47$ (d, $2 \mathrm{H}, J=7.8 \mathrm{~Hz}) ;{ }^{13} \mathrm{C} \mathrm{NMR}\left(150 \mathrm{MHz}, \mathrm{CDCl}_{3}\right) \delta_{\mathrm{C}} 159.5,149.0,146.9,140.5$,

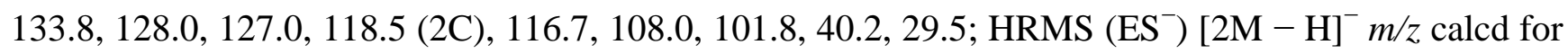
$\mathrm{C}_{32} \mathrm{H}_{27} \mathrm{O}_{8} \mathrm{Cl}_{4} 679.0460$, found 679.0482 .

The demethylation reaction was also performed on a 2:1 mixture of $\mathbf{1 1}$ and $\mathbf{2 7}$, resulting in a 2:1 mixture of $\mathbf{1 2}$ and its $(Z)$-diastereomer. Characteristic signals for the (Z)-diastereomer: ${ }^{1} \mathrm{H}$ NMR $\left(400 \mathrm{MHz}\left(\mathrm{CD}_{3}\right)_{2} \mathrm{CO}\right) \delta_{\mathrm{H}} 6.85(\mathrm{~s}, 1 \mathrm{H}), 6.48(\mathrm{t}, 1 \mathrm{H}, J=7.6 \mathrm{~Hz}), 3.81(\mathrm{~s}, 2 \mathrm{H}), 3.46(\mathrm{~d}, 2 \mathrm{H}, J=7.6 \mathrm{~Hz})$.

\subsection{Anti-Staphylococcal Activity}

Microbroth dilution assays were performed as described in the CLSI guidelines. Minimum inhibitory concentrations $\left(\mathrm{MIC}_{50}\right.$ and $\mathrm{MIC}_{90}$ ) were determined using 96-well microbroth dilution assays. Antimicrobial activity of pure compounds or antibiotic standards were tested by adding serial dilutions to wells containing Mueller Hinton II broth. An overnight growth of S. aureus ATCC 25923, MRSA ATCC BAA-41, MDRSA BAA-44, S. aureus UAMS-1, and CA-MRSA USA300-LAC was diluted in Mueller-Hinton II broth and added to the wells to a final concentration of $5 \times 10^{5}$ colony forming units (CFU) per milliliter. Plates were incubated for $18 \mathrm{~h}$ at $37{ }^{\circ} \mathrm{C}$ with shaking at $200 \mathrm{rpm}$. Absorbance at $600 \mathrm{~nm}$ is read on a Molecular Devices plate reader. Growth curves are plotted, and curves were fit to a one-site model using the equation $y=100 /\left[1+\left(\right.\right.$ concentration/ $\left.\left./ \mathrm{MIC}_{50}\right)\right]$, where 
$\mathrm{MIC}_{50}$ is the concentration at which the growth of bacterial cultures are reduced by $50 \%$. MIC 90 values were visually calculated by determining the lowest concentration of test compound that allowed no visible growth (no difference of absorption between treated samples and blank controls).

Bacteriostatic (BS) or bactericidal (BC) properties were determined by plating onto a fresh TSA plate an aliquot from each well that showed no visible growth starting at the $\mathrm{MIC}_{90}$. Plates were incubated for $24 \mathrm{~h}$ at $37{ }^{\circ} \mathrm{C}$, and colonies were counted. Bactericidal concentrations were defined as those that resulted in a three logarithmic decrease in the number of viable bacteria relative to the starting inoculum, and the lowest bactericidal concentration was defined as the MBC.

\section{Conclusions}

The rare marine chrysophyte alga $C$. taylori has yielded a number of biologically active natural products. While the occurrence of $C$. taylori has been documented at a growing number of locations globally, thus far only collections obtained from the southeastern side of St. John appear to contain the full suite of chrysophaentins. The geographical variability described here, along with temporal and seasonal changes in the abundance of $C$. taylori, limited our ability to obtain additional material for study. Nevertheless, early synthetic efforts toward the synthesis of chrysophaentin A in particular have provided fragments of the natural products that have proven useful for biological studies. Here we have expanded the antimicrobial studies of several chrysophaentins and two synthetic fragments to include drug-susceptible and drug-resistant $S$. aureus strains that are of current clinical interest. Although approximately half the size of the cyclic chrysophaentins, we have shown that the potencies and spectrum of antimicrobial activity of the synthetic fragments are comparable to those of the parent chrysophaentins, in particular to the acyclic compound chrysophaentin E. Moreover, both the natural products and synthetic fragments are equally effective against both drug-resistant and drug-susceptible $S$. aureus strains. In summary, our results show promise for the notion of synthesizing equally potent chrysophaentin analogs that will be more readily available, and provide new data on the antimicrobial spectrum of this novel class of antibiotics.

\section{Acknowledgments}

We thank the United States National Park Service for research collecting permits for the U.S. Virgin Islands, P. Dunman for clinical S. aureus strains, and M. Bewley for assistance with collections. We also thank Boehringer Ingelheim Pharmaceuticals Inc. for financial support (P.W.). This work was supported in part by the National Institutes of Health Intramural Research Program (NIDDK), and the Intramural AIDS Targeted Antiviral Program, Office of the Director, NIH (C.A.B.). J.L.K. is a recipient of a predoctoral Intramural AIDS Research Fellowship, Office of the Director, NIH.

\section{References}

1. Diekema, D.J.; Pfaller, M.A.; Schmitz, F.J.; Smayevsky, J.; Bell, J.; Jones, R.N.; Beach, M. Survey of infections due to Staphylococcus species: Frequency of occurrence and antimicrobial susceptibility of isolates collected in the United States, Canada, Latin America, Europe, and the Western Pacific region for the SENTRY Antimicrobial Surveillance Program, 1997-1999. Clin. Infect. Dis. 2001, 32 (Suppl. 2), S114-S132. 
2. Kirby, W.M. Extraction of a highly potent penicillin inactivator from penicillin resistant Staphylococci. Science 1944, 99, 452-453.

3. Barber, M.; Rozwadowska-Dowzenko, M. Infection by penicillin-resistant staphylococci. Lancet 1948, 2, 641-644.

4. Jevons, M.P. “Celbenin”-resistant Staphylococci. Br. Med. J. 1961, 1, 124-125.

5. Stewart, G.T.; Holt, R.J. Evolution of natural resistance to the newer penicillins. Br. Med. J. 1963, 1, 308-311.

6. Mato, R.; Sanches, S.I.; Venditti, M.; Platt, D.J.; Brown, A.; Chung, M.; de Lencastre, H. Spread of the multiresistant Iberian clone of methicillin-resistant Staphylococcus aureus (MRSA) to Italy and Scotland. Microb. Drug Resist. 1998, 4, 107-112.

7. Klevens, R.M.; Morrison, M.A.; Nadle, J.; Petit, S.; Gershman, K.; Ray, S.; Harrison, L.H.; Lynfield, R.; Dumyati, G.; Townes, J.M.; et al. Invasive methicillin-resistant Staphylococcus aureus infections in the United States. J. Am. Med. Assoc. 2007, 298, 1763-1771.

8. Bordon, J.; Master, R.N.; Clark, R.B.; Duvvuri, P.; Karlowsky, J.A.; Ayesu, K.; Klotchko, A.; Kapoor, R.; Ramirez, J. Methicillin-resistant Staphylococcus aureus resistance to non-beta-lactam antimicrobials in the United States from 1996 to 2008. Diagn. Microbiol. Infect. Dis. 2010, 67, 395-398.

9. Moran, G.J.; Krishnadasan, A.; Gorwitz, R.J.; Fosheim, G.E.; McDougal, L.K.; Carey, R.B.; Talan, D.A. Methicillin-resistant $S$. aureus infections among patients in the emergency department. N. Engl. J. Med. 2006, 355, 666-674.

10. Miller, L.G.; Diep, B.A. Clinical practice: Colonization, fomites, and virulence: Rethinking the pathogenesis of community-associated methicillin-resistant Staphylococcus aureus infection. Clin. Infect. Dis. 2008, 46, 752-760.

11. Baba, T.; Takeuchi, F.; Kuroda, M.; Yuzawa, H.; Aoki, K.; Oguchi, A.; Nagai, Y.; Iwama, N.; Asano, K.; Naimi, T.; et al. Genome and virulence determinants of high virulence community-acquired MRSA. Lancet 2002, 359, 1819-1827.

12. Daum, R.S.; Ito, T.; Hiramatsu, K.; Hussain, F.; Mongkolrattanothai, K.; Jamklang, M.; Boyle-Vavra, S. A novel methicillin-resistance cassette in community-acquired methicillin-resistant Staphylococcus aureus isolates of diverse genetic backgrounds. J. Infect. Dis. 2002, 186, 1344-1347.

13. Okuma, K.; Iwakawa, K.; Turnidge, J.D.; Grubb, W.B.; Bell, J.M.; O’Brien, F.G.; Coombs, G.W.; Pearman, J.W.; Tenover, F.C.; Kapi, M.; et al. Dissemination of new methicillin-resistant Staphylococcus aureus clones in the community. J. Clin. Microbiol. 2002, 40, 4289-4294.

14. Vandenesch, F.; Naimi, T.; Enright, M.C.; Lina, G.; Nimmo, G.R.; Heffernan, H.; Liassine, N.; Bes, M.; Greenland, T.; Reverdy, M.E.; et al. Community-acquired methicillin-resistant Staphylococcus aureus carrying Panton-Valentine leukocidin genes: Worldwide emergence. Emerg. Infect. Dis. 2003, 9, 978-984.

15. Lina, G.; Piemont, Y.; Godail-Gamot, F.; Bes, M.; Peter, M.O.; Gauduchon, V.; Vandenesch, F.; Etienne, J. Involvement of Panton-Valentine leukocidin-producing Staphylococcus aureus in primary skin infections and pneumonia. Clin. Infect. Dis. 1999, 29, 1128-1132. 
16. Moellering, R.C., Jr.; Abbott, G.F.; Ferraro, M.J. Case records of the Massachusetts General Hospital. Case 2-2011. A 30-year-old woman with shock after treatment of a furuncle. N. Engl. J. Med. 2011, 364, 266-275.

17. Deleo, F.R.; Otto, M.; Kreiswirth, B.N.; Chambers, H.F. Community-associated meticillin-resistant Staphylococcus aureus. Lancet 2010, 375, 1557-1568.

18. Abi-Hanna, P.; Frank, A.L.; Quinn, J.P.; Kelkar, S.; Schreckenberger, P.C.; Hayden, M.K.; Marcinak, J.F. Clonal features of community-acquired methicillin-resistant Staphylococcus aureus in children. Clin. Infect. Dis. 2000, 30, 630-631.

19. Tenover, F.C.; McDougal, L.K.; Goering, R.V.; Killgore, G.; Projan, S.J.; Patel, J.B.; Dunman, P.M. Characterization of a strain of community-associated methicillin-resistant Staphylococcus aureus widely disseminated in the United States. J. Clin. Microbiol. 2006, 44, 108-118.

20. Diep, B.A.; Stone, G.G.; Basuino, L.; Graber, C.J.; Miller, A.; des Etages, S.A.; Jones, A.; Palazzolo-Ballance, A.M.; Perdreau-Remington, F.; Sensabaugh, G.F.; et al. The arginine catabolic mobile element and staphylococcal chromosomal cassette mec linkage: Convergence of virulence and resistance in the USA300 clone of methicillin-resistant Staphylococcus aureus. J. Infect. Dis. 2008, 197, 1523-1530.

21. Gorwitz, R.J. Understanding the success of methicillin-resistant Staphylococcus aureus strains causing epidemic disease in the community. J. Infect. Dis. 2008, 197, 179-182.

22. Montgomery, C.P.; Boyle-Vavra, S.; Adem, P.V.; Lee, J.C.; Husain, A.N.; Clasen, J.; Daum, R.S. Comparison of virulence in community-associated methicillin-resistant Staphylococcus aureus pulsotypes USA300 and USA400 in a rat model of pneumonia. J. Infect. Dis. 2008, 198, 561-570.

23. Payne, D.J.; Gwynn, M.N.; Holmes, D.J.; Pompliano, D.L. Drugs for bad bugs: Confronting the challenges of antibacterial discovery. Nat. Rev. Drug Discov. 2007, 6, 29-40.

24. Newman, D.J.; Cragg, G.M. Natural products as sources of new drugs over the 30 years from 1981 to 2010. J. Nat. Prod. 2012, 75, 311-335.

25. Appelbaum, P.C. Reduced glycopeptide susceptibility in methicillin-resistant Staphylococcus aureus (MRSA). Int. J. Antimicrob. Agents 2007, 30, 398-408.

26. Zetola, N.; Francis, J.S.; Nuermberger, E.L.; Bishai, W.R. Community-acquired meticillin-resistant Staphylococcus aureus: An emerging threat. Lancet Infect. Dis. 2005, 5, 275-286.

27. Plaza, A.; Keffer, J.L.; Bifulco, G.; Lloyd, J.R.; Bewley, C.A. Chrysophaentins A-H, antibacterial bisdiarylbutene macrocycles that inhibit the bacterial cell division protein FtsZ. J. Am. Chem. Soc. 2010, 132, 9069-9077.

28. Google Earth. Image: U.S. Geological Survey, Image copyright: 2012 Digital Globe, GeoEye, Google. Available online: http://www.google.com/earth/index.html (accessed on 16 February 2012).

29. Kozlowski, M.C.; Dugan, E.C.; DiVirgilio, E.S.; Maksimenka, K.; Bringmann, G. Asymmetric total synthesis of nigerone and ent-nigerone: Enantioselective oxidative biaryl coupling of highly hindered naphthols. Adv. Synth. Catal. 2007, 349, 583-594.

30. Gopalsamuthiram, V.; Wulff, W.D. A new convergent strategy for the synthesis of calixarenes via a triple annulation of Fischer carbene complexes. J. Am. Chem. Soc. 2004, 126, 13936-13937. 
31. Bellina, F.; Colzi, F.; Mannina, L.; Rossi, R.; Viel, S. Reaction of alkynes with iodine monochloride revisited. J. Org. Chem. 2003, 68, 10175-10177.

32. Uemura, S.; Okazaki, H.; Onoe, A.; Okano, M. Chlorination and chloroiodination of acetylenes with copper(II) chloride. J. Chem. Soc. Perkin Trans. 1 1977, 6, 676-680.

33. Wright, B.J.D.; Hartung, J.; Peng, F.; van de Water, R.; Liu, H.B.; Tan, Q.H.; Chou, T.C.; Danishefsky, S.J. Synthesis of pluraflavin A "aglycone". J. Am. Chem. Soc. 2008, 130, 16786-16790.

34. Bloomer, J.L.; Stagliano, K.W.; Gazzillo, J.A. Preparation of functionalized juglone acetates and juglones via 1,4-dimethoxynaphthalene derivatives: Synthesis of anthraquinones related to rhein and aloe emodin. J. Org. Chem. 1993, 58, 7906-7912.

35. Oswald, C.L.; Carrillo-Marquez, T.; Caggiano, L.; Jackson, R.F.W. Negishi cross-coupling reactions of alpha-amino acid-derived organozinc reagents and aromatic bromides. Tetrahedron 2008, 64, 681-687.

36. Sanches, I.S.; Ramirez, M.; Troni, H.; Abecassis, M.; Padua, M.; Tomasz, A.; de Lencastre, H. Evidence for the geographic spread of a methicillin-resistant Staphylococcus aureus clone between Portugal and Spain. J. Clin. Microbiol. 1995, 33, 1243-1246.

37. Gillaspy, A.F.; Hickmon, S.G.; Skinner, R.A.; Thomas, J.R.; Nelson, C.L.; Smeltzer, M.S. Role of the accessory gene regulator (agr) in pathogenesis of staphylococcal osteomyelitis. Infect. Immun. 1995, 63, 3373-3380.

38. McDougal, L.K.; Steward, C.D.; Killgore, G.E.; Chaitram, J.M.; McAllister, S.K.; Tenover, F.C. Pulsed-field gel electrophoresis typing of oxacillin-resistant Staphylococcus aureus isolates from the United States: Establishing a national database. J. Clin. Microbiol. 2003, 41, 5113-5120.

39. Burlak, C.; Hammer, C.H.; Robinson, M.A.; Whitney, A.R.; McGavin, M.J.; Kreiswirth, B.N.; Deleo, F.R. Global analysis of community-associated methicillin-resistant Staphylococcus aureus exoproteins reveals molecules produced in vitro and during infection. Cell Microbiol. 2007, 9 , 1172-1190.

40. Bryan, H.F.; Lewis, I.F. A new protophyte from the Dry Tortugas. Am. J. Bot. 1941, 28, 343-348.

41. Gerwick, W.H.; Lopez, A.; van Duyne, G.D.; Clardy, J.; Ortiz, W.; Baez, A. Hormothamnione, a novel cytotoxic styrylchromone from the marine cyanophyte Hormothamnion enteromorphoides grunow. Tetrahedron Lett. 1986, 27, 1979-1982.

42. Gerwick, W.H. 6-Desmethoxyhormothamnione, a new cytotoxic styrylchromone from the marine cryptophyte Chrysophaeum taylori. J. Nat. Prod. 1989, 52, 252-256.

43. Harrowven, D.C.; Kostiuk, S.L. Macrocylic bisbibenzyl natural products and their chemical synthesis. Nat. Prod. Rep. 2012, 29, 223-242.

44. Asakawa, Y.; Toyota, M.; Matsuda, R.; Takikawa, K.; Takemoto, T. Distribution of novel cyclic bisbibenzyls in Marchantia and Riccardia species. Phytochemistry 1983, 22, 1413-1415.

45. Scher, J.M.; Zapp, J.; Schmidt, A.; Becker, H. Bazzanins L-R, chlorinated macrocyclic bisbibenzyls from the liverwort Lepidozia incurvata. Phytochemistry 2003, 64, 791-796.

46. Martini, U.; Zapp, J.; Becker, H. Lignans from the liverwort Bazzania trilobata. Phytochemistry 1998, 49, 1139-1146. 
47. Hashimoto, T.; Irita, H.; Takaoka, S.; Tanaka, M.; Asakawa, Y. New chlorinated cyclic bis(bibenzyls) from the liverworts Herbertus sakuraii and Mastigophora diclados. Tetrahedron 2000, 56, 3153-3159.

48. Friederich, S.; Maier, U.H.; Deus-Neumann, B.; Asakawa, Y.; Zenk, M.H. Biosynthesis of cyclic bis(bibenzyls) in Marchantia polymorpha. Phytochemistry 1999, 50, 589-598.

49. Ren, D.; Pipes, G.D.; Hambly, D.; Bondarenko, P.V.; Treuheit, M.J.; Gadgil, H.S. Top-down $N$-terminal sequencing of immunoglobulin subunits with electrospray ionization time of flight mass spectrometry. Anal. Biochem. 2009, 384, 42-48.

50. Bloomer, J.L.; Gazzillo, J.A. An efficient route to 3-chlorojuglones. Tetrahedron Lett. 1989, 30, 1201-1204.

Samples Availability: Available from the authors.

(C) 2012 by the authors; licensee MDPI, Basel, Switzerland. This article is an open access article distributed under the terms and conditions of the Creative Commons Attribution license (http://creativecommons.org/licenses/by/3.0/). 